\title{
Metal-Oxide Broken-Gap Tunnel Junction for Copper Indium Gallium Diselenide Tandem Solar Cells
}

\author{
Sang Ho Song ${ }^{1}$, Eray S. Aydil ${ }^{2}$ and Stephen A. Campbell ${ }^{1, *}$ \\ ${ }^{1}$ Dept. of Electrical and Computer Engineering, \\ ${ }^{2}$ Dept. of Chemical Engineering and Materials Science \\ University of Minnesota, Minneapolis, MN, 55414, USA
}

\begin{abstract}
A metal-oxide broken-gap heterojunction between $\mathrm{p}-\mathrm{Cu}_{2} \mathrm{O}$ and $\mathrm{n}-\mathrm{In}_{2} \mathrm{O}_{3}$ is proposed and studied for use as a tunnel junction in polycrystalline $\mathrm{CuIn}_{1-\mathrm{x}} \mathrm{Ga}_{\mathrm{x}} \mathrm{Se}_{2}$ (CIGS) based tandem solar cells using numerical device simulation. Specifically, a tandem solar cell with a $\mathrm{CuGaSe}_{2}$ (CGS) absorber top cell and a $\mathrm{CuInSe}_{2}$ (CIS) absorber bottom cell was considered. The ballistic transport model explains well the carrier transport in the broken-gap heterojunction. Broken-gap heterojunctions provide linear current-voltage characteristics even if one side is lightly doped and the junction resistance is much lower than typical values of series resistance in solar cells. However, electron affinities of metal oxides for broken-gap band alignment may induce an energy barrier between the tunnel junction and the top and bottom solar cells, degrading performance. These barriers can be reduced using buffer layers. For example, NiO and graded $\mathrm{In}_{2} \mathrm{O}_{3}-\mathrm{ZnO}$ buffer layers are proposed beneath CGS top solar cell and above the CIS bottom solar cell, respectively. With these buffer layers, the efficiencies of the top and bottom cells are $17.5 \%$ and $6.5 \%$ respectively. The modeled efficiency of the CGS/CIS tandem solar cell is $24.1 \%$ and there is virtually no significant efficiency loss due to the presence of the broken-gap junction.
\end{abstract}


Keywords - Broken-gap heterojunctions, Multi-junction photovoltaic cells, CIGS, Tunnel junction, Metal oxide, Device simulation.

*: Corresponding author

Stephen A Campbell

Professor

Department of Electrical and Computer Engineering University of Minnesota 200 Union St. SE, 4-174

Minneapolis, MN, 55455, USA

Phone: +1-612-625-6608

Fax: +1-612-625-4583

E-mail: campb001@umn.edu 


\section{Introduction}

Thin film multi-junction solar cells are among the most promising structures for thirdgeneration photovoltaic (PV) devices because they have the potential to convert sunlight to electricity with high efficiency and at low cost $[1,2]$. Single-junction thin film solar cells show low cost [3] and high efficiency [4] compared to other solar cells. However, single-junction solar cell efficiencies are constrained by the Shockley-Queisser limit [5]. Further improvements require the use of multi-junction PV device architectures [1]. Crystalline multi-junction solar cells hold the world record efficiency [6], however, they are expensive to produce due to the need for epitaxial growth [7]. It would be desirable to make multi-junction solar cells based on low-cost thin polycrystalline films such as CdTe and $\mathrm{CuIn}{ }_{1-\mathrm{x}} \mathrm{Ga}_{\mathrm{x}} \mathrm{Se}_{2}$ (CIGS).

In multi-junction PV devices two or more solar cells share the solar spectrum. The top cell should be transparent below the bandgap of its absorber and connected to the bottom cell with transparent contacts. When two solar cells are stacked monolithically, a reverse biased p-n junction forms at their interface. Typically tunnel junction (TJ) diodes are used between the solar cells to solve this problem.

This connection is one of the obstacles to making multi-junction solar cells based on polycrystalline films. The TJ requires a very heavily doped $p-n$ junction with steep doping profiles at the interface [8]. However, the dopant concentration profile control in polycrystalline films is much more difficult to achieve owing to fast grain boundary diffusion [9, 10]. Furthermore, some of the top cell layers require a high temperature deposition process to produce large grains and low trap densities. Thus, significant dopant diffusion in the bottom solar cell and inter-diffusion near the tunnel junction can occur. Furthermore, doping in most polycrystalline PV materials such as CIGS occurs via point defects, making precise doping 
concentration control very difficult and compensation common. Finally, it is impossible to form heavily doped layers of both types due to compensation effects [11,12]. To avoid these difficulties, multi terminal methods have been demonstrated [13,14]. In CIGS solar cells, $\mathrm{MoSe}_{2}$ on $\mathrm{ZnO}: \mathrm{Al}, \mathrm{SnO}: \mathrm{F}$ and $\mathrm{In}_{2} \mathrm{O}_{3}: \mathrm{Sn}$ (ITO) make good ohmic contacts with CIGS absorber, however low transmittance is a problem $[15,16,17]$. More fundamentally, tandem devices formed by stacking cost more since one loses the advantages of monolithic integration.

In this article, we examine the possibility of using metal-oxide broken-gap heterojunctions as the tunnel junction in multi-junction CIGS solar cells. We investigated the I-V characteristics of $\mathrm{p}-\mathrm{Cu}_{2} \mathrm{O} / \mathrm{n}-\mathrm{In}_{2} \mathrm{O}_{3}$ junction. Early experimental results show ohmic behavior at a similar junction made from $\mathrm{p}-\mathrm{Cu}_{2} \mathrm{O} / \mathrm{n}-\mathrm{ZnSnO}_{3}[18]$. Here we also investigate monolithic CIGSbased tandem PV device with $\mathrm{p}-\mathrm{Cu}_{2} \mathrm{O} / \mathrm{n}-\mathrm{In}_{2} \mathrm{O}_{3}$ junction where the top and bottom cell absorbers were $\mathrm{CuGaSe}_{2}$ (CGS) and $\mathrm{CuInSe}_{2}$ (CIS) respectively, including the band alignment of brokengap heterojunctions with top and bottom solar cells.

It is important to point out that major obstacles exist to realizing a high-efficiency tandem cell. The top (i.e. wide bandgap) cell is critical to the efficiency. Its larger $\mathrm{V}_{\mathrm{OC}}$ means that it must provide about two thirds of the total power. CGS has a suitable band gap for the top solar cell in tandem devices. However, the best efficiency of CGS solar cells is only about $10 \%$. This is due to a large bulk trap density [19] and poor band alignment between CGS and the buffer layer $[20,21]$ which lead to a low open circuit voltage [22,23]. A second obstacle is thermal budget. The deposition of a low defect density wide bandgap absorber typically requires high temperature. A pore structure forms in the CdS upon annealing leading to a heavy diffusion of $\mathrm{Ga}$ into $\mathrm{ZnO}$ layer. Ga-assisted Cd diffusion may be responsible for the pore formation [24]. Furthermore, diffusion of $\mathrm{Cd}$ in the lower device counter dopes the absorber leading to a severe 
drop in open circuit voltage once the device is fully depleted [25]. The next possible problem is the use of CIS in the lower device. Although CIS has not demonstrated an efficiency as high as CIGS, Solar Frontier recently demonstrated a low Ga content $20.9 \%$ cell with a bandgap of only $1.05 \mathrm{eV}$ [26]. Since this low concentration of gallium only increases the desired top cell from 1.65 to $1.70 \mathrm{eV}$, this problem has largely been resolved. As a result of the first two technical limitations, the device efficiency predicted here cannot be realized today. However, progress is being made. Not only are the efficiencies of CGS solar cells rising [27,28], but alternative wide bandgap CIGS-based materials are also being explored [29]. Shafarman has been developing $\mathrm{Cu}_{\mathrm{x}} \mathrm{Ag}_{1-\mathrm{x}} \mathrm{In}_{\mathrm{y}} \mathrm{Ga}_{1-\mathrm{y}} \mathrm{Se}_{2}[30]$ and has recently demonstrated relatively high efficiency $1.4 \mathrm{eV}$ devices. We have demonstrated very low trap density absorbers at $1.6 \mathrm{eV}$ using UHV-deposited $\mathrm{CuIn}_{x} \mathrm{Al}_{y} \mathrm{Ga}_{1-\mathrm{x}-\mathrm{y}} \mathrm{Se}_{2}$ [29,31], but have not yet demonstrated a high efficiency device. In this work we focus on the effects of the broken-gap heterojunction under high performance conditions.

\section{Metal oxide broken-gap heterojunction}

While high conductivity transparent conducting oxides (TCOs) $[32,33]$ are used as window layers in solar cells [34] they are difficult to heavily dope both electrons and holes making them poor candidates for tunnel junctions $[35,36]$. When the doping concentration is increased and Fermi level reaches the formation energy of a compensating defect, the net carrier concentration saturates in an effect called pinning [21]. Thus, one cannot form a heavily doped p-type film from materials such as $\mathrm{ZnO}, \mathrm{SnO}_{2}, \mathrm{In}_{2} \mathrm{O}_{3}, \mathrm{Ga}_{2} \mathrm{O}_{3}$, and $\mathrm{CdO}$. Similarly, one cannot form a heavily doped n-type film from $\mathrm{Cu}_{2} \mathrm{O}, \mathrm{NiO}$ and $\mathrm{CuMO}_{2}(\mathrm{M}=\mathrm{Al}, \mathrm{In}, \mathrm{Cr}$ and $\mathrm{Ga})$.

It is possible to use a heterojunction of an n-type and a p-type metal oxide for a tunnel junction. A broken-gap metal-oxide heterojunction is a promising design. This involves a 
junction between two dissimilar materials where the conduction band edge of the n-type material is equal to or lower in energy than the valence band edge of the p-type material as shown in Fig. 1. Carriers can easily move across an interface with this band alignment by a nonlocal interband transition. As a result the junction has linear current-voltage (I-V) characteristics [37] even without heavy doping on both sides.

The electrical characteristics of the broken-gap heterojunction have been studied extensively in InAs/GaSb junctions [37-41]. The valence band edge of GaSb is between 0.48 and $0.53 \mathrm{eV}$ higher than that of InAs. The band overlap ( $\Delta \chi$ as shown in Fig. 1) is between 0.12 and $0.17 \mathrm{eV}$ since band gaps of InAs and of $\mathrm{GaSb}$ are $0.36 \mathrm{eV}$ and $0.71 \mathrm{eV}$, respectively [38]. The transport properties depend on the band bending near the junction interface. When an n-InAs/p$\mathrm{GaSb}$ approaches flat band, the I-V characteristics are linear [38,39,40]. A resistance as low as $10^{-7} \Omega-\mathrm{cm}^{2}$ can be achieved [41] suggesting no significant contribution to $\mathrm{R}_{\text {series }}$.

When designing a broken-gap tunnel junction, the electron affinities of the materials are the most important properties. Low and high electron affinities are desired for the n- and p-type materials, respectively. P-type TCOs are rare $\mathrm{Cu}_{2} \mathrm{O}$ and $\mathrm{CuAlO}_{2}$ are two of the most attractive materials for broken-gap tunnel junctions since they have the lowest electron affinities among the p-type TCOs. In n-type TCOs, $\mathrm{SnO}_{2}, \mathrm{GaInO}_{3}$ and $\mathrm{ZnSnO}_{3}$ are the most likely to form brokengap band alignment with other TCOs for a similar reason [33].

There are few studies on broken-gap heterojunction with metal oxide films. Tanaka et al. studied the heterojunctions formed between $\mathrm{Cu}_{2} \mathrm{O}$ and several different n-type TCOs including $\mathrm{ZnO}$, ITO and $\mathrm{In}_{2} \mathrm{O}_{3}$ [42]. Unlike junctions with other n-type TCOs, the $\mathrm{p}-\mathrm{Cu}_{2} \mathrm{O} / \mathrm{n}$ - $\mathrm{In}_{2} \mathrm{O}_{3}$ junction showed linear $\mathrm{I}-\mathrm{V}$ characteristics while the $\mathrm{p}-\mathrm{Cu}_{2} \mathrm{O} / \mathrm{n}$-ITO junction showed nonlinear $\mathrm{I}-\mathrm{V}$ characteristics with a low energy Schottky barrier [42]. The band alignment of these ohmic p- 
$\mathrm{Cu}_{2} \mathrm{O} / \mathrm{n}-\mathrm{In}_{2} \mathrm{O}_{3}$ junctions was not studied, however it can be estimated from the $\mathrm{I}-\mathrm{V}$ results and the band alignment of the $\mathrm{Cu}_{2} \mathrm{O} / \mathrm{ITO}$ junction, and the electron affinity difference between ITO and $\mathrm{n}-\mathrm{In}_{2} \mathrm{O}_{3}$. Recently, Deuermeier et al. analyzed the band alignment of $\mathrm{p}-\mathrm{Cu}_{2} \mathrm{O} / \mathrm{n}-\mathrm{ITO}$ by X-ray photoemission spectroscopy (XPS). They found that the conduction band edge of n-ITO is 0.2 to $0.7 \mathrm{eV}$ higher than the valence band edge of $\mathrm{p}-\mathrm{Cu}_{2} \mathrm{O}$ depending on the ITO deposition conditions [43]. According to research results from multiple groups [33,44] the work function of $\operatorname{In}_{2} \mathrm{O}_{3}$ is 0.2 to $0.8 \mathrm{eV}$ lower than that of ITO. From these results, it can be estimated that $\mathrm{p}-\mathrm{Cu}_{2} \mathrm{O} / \mathrm{n}-\mathrm{In}_{2} \mathrm{O}_{3}$ junctions have a broken-gap band alignment. The linear I-V characteristic supports this inference.

\section{Device simulation.}

Numerical simulation for the tunnel junction in a complete monolithic tandem solar cell requires current continuity and the Poisson equation, as well as a self-consistent treatment of quantum mechanical transport in the tunnel junction. However, well-known solar cell simulations do not have this capability. Thus, previous tandem device modeling has simply treated the tunnel junction as an ohmic contact between the top and bottom solar cells [45,46]. Here we use DESSIS - a commercially available multi physics device simulation tool for numerical simulation. Quantum transport at the broken-gap junction is solved by the WentzelKramers-Brillouin (WKB) approximation. Device simulation is performed by self-consistently solving the current continuity equation, the Poisson equation and WKB approximation near the broken-gap junction interface. Optical absorption in the stacked multiple layers is calculated by transfer matrix methods [47].

\section{Transport models and simulation results of $\mathrm{p}-\mathrm{Cu}_{2} \mathrm{O} / \mathrm{n}-\mathrm{In}_{2} \mathrm{O}_{3}$ heterojunction.}




\subsection{Nonlocal interband transition model vs. ballistic transport model.}

Fig. 2a shows the equilibrium band diagram of the $\mathrm{p}-\mathrm{Cu}_{2} \mathrm{O} / \mathrm{n}-\mathrm{In}_{2} \mathrm{O}_{3}$ heterojunction. As previously shown for the $\mathrm{Cu}_{2} \mathrm{O} / \mathrm{ITO}$ heterojunction [43], the band alignment can vary with film deposition conditions. We varied the band overlap from $0.0 \mathrm{eV}$ to $0.2 \mathrm{eV}$ to study the effect. For these calculations, the doping concentrations on both sides of the junction were taken to be $1.5 \times 10^{19} \mathrm{~cm}^{-3}$ and the thickness of each layer was set to $200 \mathrm{~nm}$. According to the Anderson model [48], the Fermi level should be constant. Also, the energy band discontinuity must be maintained at the interface. The energy bands bend at the interface to satisfy these requirements [48]. As shown in Fig. 2b, band bending induces a carrier accumulation on both sides of the junction. The wider the band overlap $(\Delta \chi)$, the higher the accumulation layer concentrations.

Next we studied transport. An accurate solution for carrier transport in a broken-gap heterojunction can be obtained by solving Schrodinger's and Poisson's equations selfconsistently [49,50]. Quantum transport near the junction interface can also be treated by the WKB approximation. Carrier transport is modeled by solving both the interband transition and the drift-diffusion transport in the quasi-neutral region simultaneously. The band alignment of the heterojunction affects both the electric field and the carrier concentration at the interface as described above [51]. Clearly these are important for the drift-diffusion model. Band bending at the interface is also very important since the shape of the potential strongly affects the transmission coefficient.

In addition to interband transition at the interface, ballistic transport may occur between the edge of the charge neutral region and the junction interface ((3) in Fig. 3) when the accumulation width is narrow and the field is large. Ballistic transport occurs when electrons 
travel without losing energy by scattering [52]. Electrons in the accumulation region are accelerated by a strong built-in electric field, reaching velocities substantially higher than the saturated or terminal velocity. This is the so-called velocity overshoot effect. The electrons eventually scatter and lose the kinetic energy acquired from the field if the accumulation region is wide enough [52]. Since the scattering rate increases with kinetic energy, ballistic transport happens within a narrow region. Thus, electrons can move ballistically across the accumulation region only if the accumulation width is narrower than about $10 \mathrm{~nm}$ [52].

In this work, we simulate ballistic transport from the edge of charge neutral region to the junction interface using the WKB approximation since ballistic transport conserves the sum of the kinetic and potential energies. In this model the transmission probability can be calculated for arbitrary potential shapes. The carrier energy can be larger or smaller than the potential barrier. Interband tunneling current from the valence band to the conduction band $\left(J_{c v}\right)$ is given by

$$
J_{C V}=-q \int_{0^{+}}^{\infty}\left[R_{C V}(x)-G_{C V}(x)\right] d x
$$

where the difference between the recombination $\left(R_{c v}\right)$ and generation rates $\left(G_{c v}\right)$ is given as

$$
\begin{aligned}
& R_{C}(x)-G_{C}(x)=\frac{A_{C}{ }^{*}}{q k}\left(\frac{d E_{V}(x)}{d x}\right) \Gamma_{C}(\varepsilon, x) \times \\
& {\left[T_{p}(x) \log \left\{1+\operatorname{Exp}\left(\frac{E_{F p}(x)-\varepsilon}{k T(x)}\right)\right\}-T_{n}\left(0^{-}\right) \log \left\{1+\operatorname{Exp}\left(\frac{E_{F n}\left(0^{-}\right)-\varepsilon}{k T\left(0^{-}\right)}\right)\right\}\right] .}
\end{aligned}
$$

In Eq. $2, A_{c v}{ }^{*}$ is the Richardson constant, $E_{F p, n}$ is Fermi level of hole and electron, $\varepsilon$ is the carrier energy, $E_{v}$ is the valence band edge energy, $q$ is charge, $k$ is the Boltzmann constant, $T$ is temperature and $T_{n}$ and $T_{p}$ are the transmission coefficients at the interface which is due to velocity mismatch for electrons and holes, respectively [47]. Here $x=0^{-}$refers to the position 
where tunneling begins. We assume that the transmission coefficients are unity since the carriers that move across the junction recombine quickly with the majority carriers. The tunneling probability $\left(\Gamma_{c v}\right)$ is given by

$$
\Gamma_{C V}(\varepsilon, x)=\exp \left[-2 \int_{0}^{r} \kappa\left(x^{\prime}, \varepsilon\right) d x^{\prime}\right],
$$

where, $\kappa, \varepsilon$ and $x$ are the wave vector, the energy of carriers and position respectively. The wave vector, $\kappa$, is

$$
\kappa=\frac{\kappa_{C} \kappa_{V}}{\sqrt{\kappa_{C}^{2}+\kappa_{V}^{2}}}
$$

where,

$$
\kappa_{C, V}=\frac{\sqrt{2 m_{0} m_{e, h} * \pm\left(E_{C, V}(x)-\varepsilon\right)}}{\hbar},
$$

$\hbar, m_{e}, m_{h}, E_{C}$ and $E_{V}$ are the reduced Planck constant, the effective masses of the electron and the hole and the conduction band edge energy of n-type material and the valence band edge energy of the p-type material, respectively [47]. Parameters used in the simulations are listed in Table 1. Parameters for the CIGS solar cell simulations were taken from Song et al. [53].

We studied the I-V characteristics of a p- $\mathrm{Cu}_{2} \mathrm{O} / \mathrm{n}-\mathrm{In}_{2} \mathrm{O}_{3}$ broken-gap heterojunctions and compared the two tunneling models described above. Even though a band overlap exists, the I-V characteristic of the broken-gap junction is linear as proven in n-InAs/p-GaSb junction.

Fig. 4 compares the I-V characteristics of the $\mathrm{p}-\mathrm{Cu}_{2} \mathrm{O} / \mathrm{n}-\mathrm{In}_{2} \mathrm{O}_{3}$ junction calculated using the interface interband transition model (Fig. 4a) and the ballistic transport model (Fig. 4b). Under near flat-band conditions where the band overlap is zero, both tunneling models predict linear I-V characteristics in the reverse bias region. However significant differences exist 
between the two model predictions when there is band overlap. A cutoff voltage $\left(\mathrm{V}_{\mathrm{C}}\right)$ appears for the interface interband transition model in reverse bias when the band overlap is wider than 0.1 $\mathrm{eV}$. Since the junction must be operated in reverse bias in multijunction solar cells, only small voltage drops can be allowed.

Band bending creates an electric field which induces a drift current toward the junction. At thermal equilibrium, the carrier concentration profile must be such that the induced diffusion current cancels the drift current for both carriers. According the simulation results shown in Fig. 4a, even if a small bias is applied, when carriers are accumulated at the interface the diffusion current cancels the drift current. Thus no significant current flows. From this effect, we can estimate the cutoff voltage analytically by calculating a flat band voltage at which carriers are not accumulated. As shown in Fig. 2a, the energy difference from the valence band edge of ptype area to the conduction band edge of n-type area in the charge neutral region is $49 \mathrm{meV}$. When the band overlaps are 0.1 and $0.2 \mathrm{eV}$ this difference is $-51 \mathrm{mV}$ and $-0.151 \mathrm{~V}$ respectively. The corresponding cutoff voltages calculated by simulation are $-61 \mathrm{mV}$ and $-0.16 \mathrm{~V}$, respectively, in good agreement with the analytical calculation. A wider band overlap increases the band bending and so requires a larger reverse bias to remove the accumulated carriers at the interface.

Under forward bias, band bending and therefore carrier accumulation increases at the interface. The diffusion current by accumulated carriers also increases and cancels out the drift current. An applied reverse bias reduces the band bending and the accumulated carrier concentration. The current does not flow until the accumulated carriers are removed. After the band is flat, majority carriers are injected to the interface by drift, thus current flows through the device. When the band overlap is zero no carriers are accumulated at thermal equilibrium. Carrier accumulation begins at $0.124 \mathrm{~V}$ in forward bias. Thus current flow below $0.124 \mathrm{~V}$ and 
peak voltage $\left(V_{P}\right)$ is observed in $\mathrm{I}-\mathrm{V}$ characteristics. However, the experimentally measured I-V characteristics of InAs/GaSb broken-gap heterojunctions with band overlap do not show a cutoff voltage. Thus, the interface transition model fails to explain the observed I-V characteristics [37$41]$.

By contrast, the I-V characteristics of a broken-gap heterojunction predicted using a ballistic transport model is linear and exhibit current flow both in forward and reverse bias as shown in Fig. 4b. Since ballistic transport occurs directly between the charge neutral region and the interface, the transmission coefficient depends only on the barrier shape and not on the profiles of accumulated carriers near the interface. For carriers to move ballistically the charge accumulation width should be narrower than the ballistic mean free path and the electric field should be high. In the $\mathrm{p}-\mathrm{Cu}_{2} \mathrm{O} / \mathrm{n}-\mathrm{In}_{2} \mathrm{O}_{3}$ junction studied here, the charge accumulation widths on both sides of the junction are less than $4 \mathrm{~nm}$ as shown in Fig. 2 and the maximum electric field is $1 \mathrm{MV} / \mathrm{cm}$. These narrow depletion widths and high electric fields lead to carrier conduction by ballistic transport across this junction. Increasing the energy band overlap produces a higher electric field at the interface making ballistic tunneling more likely. The resistance due to ballistic transport is determined by the transmission coefficient. When the transmission coefficient is one, the resistance of ballistic transport at the interface is lower than the series resistance of the charge neutral region. As a result, the series resistance of junction does not determine the I-V characteristics. Thus, the I-V characteristics do not depend on the width of the band overlap $(\Delta \chi)$. This is the reason that a broken band-gap junction can achieve a junction resistance as low as $10^{-7} \Omega-\mathrm{cm}^{2}$ in InAs/GaSb junctions. We note that in a tandem device operating under unconcentrated sunlight will generate about $20 \mathrm{~mA} / \mathrm{cm}^{2}$. For a $1 \mathrm{mV}$ potential 
drop at the tunnel junction, the maximum allowable resistance could be as high as $5 \times 10^{-2} \Omega-\mathrm{cm}^{2}$, suggesting that a broken-gap tunnel junction could easily achieve this goal.

\subsection{The effect of doping concentration.}

One of difficulties in fabricating a tunnel junction is maintaining steep doping profiles near the junction in the heavily doped n- and p-type layers. However, the energy band alignment of the broken-gap heterojunction is such that the Fermi level is located in the conduction and valence bands of the $\mathrm{n}$ - and p-type layers, respectively, and conduction can occur even when these layers are only lightly doped. Although many n-type TCOs can be doped higher than $1 \times 10^{20} \mathrm{~cm}^{-3}$, heavily doped p-type TCOs are much more difficult to achieve. We therefore investigate the effect on hole concentration in $\mathrm{Cu}_{2} \mathrm{O}$ when the electron concentration in $\operatorname{In}_{2} \mathrm{O}_{3}$ is $5 \times 10^{19} \mathrm{~cm}^{-3}$. The thicknesses of $\mathrm{n}$ and p-type layers were fixed at $200 \mathrm{~nm}$.

The model results show a peak voltage $\left(V_{P}\right)$ or cutoff voltage $\left(V_{C}\right)$ in $I-V$ characteristics when the hole concentration is low. Fig. 5a shows the typical I-V characteristics and energy band diagrams in each different carrier transport region of the $\mathrm{p}-\mathrm{Cu}_{2} \mathrm{O} / \mathrm{n}-\mathrm{In}_{2} \mathrm{O}_{3}$ junction with a hole concentration in $\mathrm{Cu}_{2} \mathrm{O}$ of $10^{17} \mathrm{~cm}^{-3}$. At thermal equilibrium (point $\mathrm{A}$ ), the $\mathrm{Cu}_{2} \mathrm{O}$ band is pulled down near the interface due to the heavy dopant concentration in the $\operatorname{In}_{2} \mathrm{O}_{3}$. Thus the valence band edge of $\mathrm{Cu}_{2} \mathrm{O}$ in the charge neutral region is higher than the conduction band of $\operatorname{In}_{2} \mathrm{O}_{3}$. In reverse bias (point $\mathrm{B}$ ), band bending increases the electron concentrations in $\mathrm{p}-\mathrm{Cu}_{2} \mathrm{O}$ at the interface. Electrons are injected into the $n-\operatorname{In}_{2} \mathrm{O}_{3}$ across the junction by interband transition. Under a small forward bias, electrons move from $n-\mathrm{In}_{2} \mathrm{O}_{3}$ to $\mathrm{p}-\mathrm{Cu}_{2} \mathrm{O}$ by not only diffusion but also interband transition at the interface. This continues until the valence band edge of $\mathrm{Cu}_{2} \mathrm{O}$ is equal to the conduction band edge of $\operatorname{In}_{2} \mathrm{O}_{3}$ (point $\mathrm{C}$ ). At this point the interband transition at the 
interface is blocked by the band gap of $\mathrm{Cu}_{2} \mathrm{O}$ and only the small diffusion current remain. Thus the current changes abruptly (point $\mathrm{C}$ ). This abrupt current change produces the negative differential resistance (NDR) often associated with tunnel junctions. NDR of a broken-gap heterojunction was observed in $\mathrm{InAs} / \mathrm{GaSb}$ heterojunction at moderate doping concentration when the dopant concentrations of n-type InAs and p-type GaSb is $2 \times 10^{17}$ and $5 \times 10^{18} \mathrm{~cm}^{-3}$ respectively [54]. Since the diffusion current increases exponentially with voltage in this regime, at sufficiently high voltage (point D), one finds a measurable current once again. The peak voltage is the voltage which makes the energy band flat. It is determined by the difference between the valence band edge of $\mathrm{Cu}_{2} \mathrm{O}$ in charge neutral region and the conduction band edge of $\mathrm{In}_{2} \mathrm{O}_{3}$ in charge neutral region at thermal equilibrium. When valence band edge of $\mathrm{Cu}_{2} \mathrm{O}$ is higher than the conduction band edge of $\operatorname{In}_{2} \mathrm{O}_{3}$ the peak voltage becomes positive. In the reverse bias case, the peak voltage changes to a cutoff voltage since carriers cannot transport across the junction until the energy band becomes flat. Thus at sufficiently low carrier concentrations the peak voltage becomes the cutoff voltage.

Fig. $5 \mathrm{~b}$ shows the band diagrams of $\mathrm{p}-\mathrm{Cu}_{2} \mathrm{O} / \mathrm{n}-\mathrm{In}_{2} \mathrm{O}_{3}$ with $\mathrm{Cu}_{2} \mathrm{O}$ dopant concentrations of $1 \times 10^{16}, 2 \times 10^{17}$ and $1 \times 10^{18} \mathrm{~cm}^{-3}$. For the last two, the cutoff voltage is positive. When the dopant concentration of $\mathrm{Cu}_{2} \mathrm{O}$ becomes $1 \times 10^{16} \mathrm{~cm}^{-3}$ the valence band edge of $\mathrm{Cu}_{2} \mathrm{O}$ is lower than the conduction band edge of $\operatorname{In}_{2} \mathrm{O}_{3}$ and cutoff voltage is $-0.11 \mathrm{~V}$. No peak voltage is observed. Thus, broken-gap junctions provide low resistance ohmic junctions, however, both sides of the junction need to be at least moderately doped. This is in sharp contrast to conventional tunnel junctions which require very heavy doping on both sides of the junction.

\section{Top and bottom single solar cells with $\mathrm{Cu}_{2} \mathrm{O} / \mathrm{In}_{2} \mathrm{O}_{3}$ heterojunction interface.}


Next, the performance of top and bottom CIGS-based solar cells with a p- $\mathrm{Cu}_{2} \mathrm{O} / \mathrm{n}-\mathrm{In}_{2} \mathrm{O}_{3}$ tunnel junction was investigated. For tandem PV devices, the optimized band gaps of the top and the bottom solar cells under AM 1.5 illumination are $1.64 \mathrm{eV}$ and $0.94 \mathrm{eV}$, respectively [55]. The band gap of the CIGS material system approximately covers this range and can be varied from $1.01 \mathrm{eV}$ for $\mathrm{CuInSe}_{2}$ (CIS) to $1.68 \mathrm{eV}$ for $\mathrm{CuGaSe}_{2}$ (CGS) Thus, we chose CGS and (CIS) for the absorber layers in the top and bottom cells, respectively.

\subsection{Top CGS solar cell to $\mathrm{Cu}_{2} \mathrm{O}$ heterojunction interface.}

The device structures and performance results of top solar cells with a broken-gap heterojunction are shown in Fig. 6a. The window layers were comprised of a $150 \mathrm{~nm}$ thick ntype $\mathrm{ZnO}: \mathrm{Al}$ and a $100 \mathrm{~nm}$ thick n-type $\mathrm{ZnO}$. The dopant concentrations of the $150 \mathrm{~nm}$ thick and $100 \mathrm{~nm}$ thick n-ZnO were $10^{19} \mathrm{~cm}^{-3}$ and $10^{17} \mathrm{~cm}^{-3}$, respectively. A $70 \mathrm{~nm}$ thick n-type $\left(5 \times 10^{15}\right.$ $\mathrm{cm}^{-3}$ ) CdS was used as a buffer layer between the CGS and the n-ZnO. A $1.6 \mu \mathrm{m}$ thick p-type $\left(10^{16} \mathrm{~cm}^{-3}\right)$ CGS layer was used for the absorber layer. A $10 \mathrm{~nm}$ thick $\mathrm{MoSe}_{2}$ was used for the contact layer between the top solar cell and the broken-gap heterojunction. The valence band edge of $\mathrm{MoSe}_{2}$ (at $5.6 \mathrm{eV}$ below vacuum level) is close to valence band of CGS (at $5.68 \mathrm{eV}$ below vacuum level). As a result, $\mathrm{MoSe}_{2}$ forms an ohmic contact with CGS. We assumed that this layer has the same optical (n-k) parameters as sputtered $\mathrm{MoSe}_{2}$ [56]. The doping concentration of $\mathrm{MoSe}_{2}$ was taken to be $10^{18} \mathrm{~cm}^{-3}$. Since $\mathrm{Cu}_{2} \mathrm{O}$ is a p-type material $\left(10^{19} \mathrm{~cm}^{-3}\right)$ it should contact the CGS absorber of the top cell. A $100 \mathrm{~nm}$ thick p-type $\mathrm{Cu}_{2} \mathrm{O}$ was placed below the $\mathrm{MoSe}_{2}$ to complete the top cell.

Fig. $6 \mathrm{~b}$ shows the valence band diagrams near the interface between the top solar cell and ideal ohmic contact (solid lines), $\mathrm{Cu}_{2} \mathrm{O}$ (dotted line) and $\mathrm{NiO}$ buffer and $\mathrm{Cu}_{2} \mathrm{O}$ (dashed line). 
When the bottom contact is ohmic, the valence band of CGS bends toward the Fermi level. Holes in valence band of CGS move easily to the bottom contact because there is no barrier between the top solar cell and the bottom contact. The reported valence band edges of $\mathrm{MoSe}_{2}$ and $\mathrm{Cu}_{2} \mathrm{O}$ are $5.6 \mathrm{eV}$ [57] and $5.1 \mathrm{eV}$ [43], respectively, so that a $0.5 \mathrm{eV}$ energy difference exists between these two materials. Therefore, when $\mathrm{Cu}_{2} \mathrm{O}$ is directly contacted with $\mathrm{MoSe}_{2}$ an energy barrier is formed on the valence band of CGS. Since the extremely thin layer of $\mathrm{MoSe}_{2}$ is fully depleted and the dopant concentration of CGS is lower than that of $\mathrm{Cu}_{2} \mathrm{O}$, CGS is depleted from the bottom contact. This barrier would block hole transport to the tunnel junction. To reduce this barrier, we introduced a p-type buffer layer between the $\mathrm{MoSe}_{2}$ and $\mathrm{Cu}_{2} \mathrm{O}$. The valence band edge of buffer materials is located between the valence band edge of $\mathrm{CGS}$ and $\mathrm{Cu}_{2} \mathrm{O}$. $\mathrm{NiO}$ is a good candidate as shown in Table 1 [44]. When $50 \mathrm{~nm}$ of p-type $\left(10^{18} \mathrm{~cm}^{-3}\right) \mathrm{NiO}$ is inserted between $\mathrm{MoSe}_{2}$ and $\mathrm{Cu}_{2} \mathrm{O}$, the barrier height in CGS is reduced from $0.26 \mathrm{eV}$ to $0.12 \mathrm{eV}$. Another barrier is generated in $\mathrm{NiO}$ at the interface between $\mathrm{NiO}$ and $\mathrm{Cu}_{2} \mathrm{O}$, however, due to the high dopant concentration in $\mathrm{NiO}$, the barrier height and width is narrow $(7 \mathrm{~nm})$ and low $(0.1$ eV). Therefore it does not affect hole transport.

The I-V characteristics and the performance summary of the top solar cells in Fig. 6a are shown in Fig. 6c and Table 2 respectively. With an ideal ohmic bottom contact (solid line in Fig. $6 \mathrm{c})$, the short circuit current $\left(\mathrm{J}_{\mathrm{SC}}\right)$ and open circuit voltage $\left(\mathrm{V}_{\mathrm{OC}}\right)$ are $18.77 \mathrm{~mA} / \mathrm{cm}^{2}$ and $1.154 \mathrm{~V}$ respectively and the efficiency of top solar cell is $18.7 \%$. When $\mathrm{Cu}_{2} \mathrm{O}$ is connected directly to $\mathrm{MoSe}_{2}$ (dotted line in Fig. 6c) $\mathrm{J}_{\mathrm{SC}}$ and $\mathrm{V}_{\mathrm{OC}}$ are $18 \mathrm{~mA} / \mathrm{cm}^{2}$ and $1.134 \mathrm{~V}$ and the efficiency decreases to $17.0 \%$. The $\mathrm{J}_{\mathrm{SC}}$ loss, $5 \%$, is the main factor in reducing the efficiency. The insertion of the $\mathrm{NiO}$ buffer layer between $\mathrm{MoSe}_{2}$ and $\mathrm{Cu}_{2} \mathrm{O}$ recovers $\mathrm{J}_{\mathrm{SC}}$ to $18.44 \mathrm{~mA} / \mathrm{cm}^{2}$ by reducing the 
barrier (dashed line in Fig. 6c). The efficiency rebounds to 17.9\%, showing that the $\mathrm{NiO}$ buffer layer is effective in improving device efficiency.

\subsection{Bottom CIS solar cell to $\operatorname{In}_{2} \mathrm{O}_{3}$ heterojunction interface.}

Fig. 7a shows the device structures that were simulated and the performance of bottom solar cells with a broken-gap heterojunction. A $100 \mathrm{~nm}$ thick n-type $\mathrm{ZnO}\left(10^{17} \mathrm{~cm}^{-3}\right)$ was used for the $\mathrm{n}$-side of the $\mathrm{p}$-n junction and a $70 \mathrm{~nm}$ thick n-type $\left(5 \times 10^{15} \mathrm{~cm}^{-3}\right) \mathrm{CdS}$ buffer layer was placed between the n-type $\mathrm{ZnO}$ and $2 \mu \mathrm{m}$ thick p-type $\left(10^{16} \mathrm{~cm}^{-3}\right) \mathrm{CIS}$ absorber. In single junction solar cells, low resistivity TCOs are deposited on top of the $\mathrm{ZnO}$ window layer to reduce the series resistance due to lateral conduction in resistive $\mathrm{ZnO}$. However, in the bottom cell, current only flows vertically. Lateral conduction occurs only in the top cell. Therefore, a TCO window layer is not required in the bottom solar cell.

Conduction band diagrams of bottom solar cells are shown in Fig. 7b. With $\operatorname{In}_{2} \mathrm{O}_{3}$ on top of the bottom cell, an energy barrier is formed in the conduction band at the interface between $\mathrm{ZnO}$ and $\mathrm{In}_{2} \mathrm{O}_{3}$ (dotted line in Fig. 7b). This happens because the electron affinity of $\operatorname{In}_{2} \mathrm{O}_{3}$ is lower (5.1 eV [44] below the vacuum level) than that of $\mathrm{ZnO}$ (4.5 eV [33] below the vacuum level). It has been reported that a low resistivity TCO can be formed [58]. Then the composition of $\mathrm{In}_{2} \mathrm{O}_{3}-\mathrm{ZnO}$ film (IZO) can be graded to eliminate the barrier. Fig. $7 \mathrm{~b}$ shows the conduction band diagrams of top solar cells with $100 \mathrm{~nm}$ thick $\operatorname{In}_{2} \mathrm{O}_{3}$ and $50 \mathrm{~nm}$ thick $\operatorname{In}_{2} \mathrm{O}_{3}$ and $50 \mathrm{~nm}$ thick compositionally graded $\mathrm{ZnO}$ to $\operatorname{In}_{2} \mathrm{O}_{3}$ from top surface of the bottom solar cell removing the energy barrier between $\mathrm{In}_{2} \mathrm{O}_{3}$ and $\mathrm{ZnO}$.

The I-V characteristics and performance summary of top solar cells in Fig. 7a are shown in Fig. 7c and Table 3 respectively. With an ohmic contact on top of the bottom cell, $\mathrm{J}_{\mathrm{SC}}$ and $\mathrm{V}_{\mathrm{OC}}$ 
are $38.52 \mathrm{~mA} / \mathrm{cm}^{2}$ and $0.493 \mathrm{~V}$ respectively. The efficiency of the bottom solar cell is $14.3 \%$ under AM 1.5 illumination. However, the bottom solar cell must share the solar spectrum with top cell. We calculated the component of the solar spectrum reaching the bottom cell assuming the full tandem structure (screened spectrum). Then $\mathrm{J}_{\mathrm{SC}}, \mathrm{FF}$, and $\mathrm{V}_{\mathrm{OC}}$ are $18.76 \mathrm{~mA} / \mathrm{cm}^{2}, 75.1 \%$ and $0.473 \mathrm{~V}$ respectively, and the efficiency decreases to $6.67 \%$. With $\operatorname{In}_{2} \mathrm{O}_{3}$ on top of the bottom solar cell, the power conversion efficiency decreases to $5.77 \%$ under the screened spectrum. The decrease in efficiency is due to the reduction in the $\mathrm{J}_{\mathrm{SC}}$ and FF to $17.86 \mathrm{~mA} / \mathrm{cm}^{2}$ and $68.18 \%$ respectively compared to the bottom cell with an ohmic contact. The energy barrier in $\mathrm{ZnO}$ at the interface between $\mathrm{ZnO}$ and $\mathrm{In}_{2} \mathrm{O}_{3}$ hinders electron transport and induces a kink in the I-V characteristic near the open circuit voltage as shown in Fig. 7c. This kink degrades the FF. According to Gloeckler et al. this forward bias kink is due to an electron barrier in the conduction band at the CIGS/CdS interface. The kink occurs when the conduction band edge of CdS is much higher than that of CIGS [59]. Similarly, the large conduction band discontinuity between $\operatorname{In}_{2} \mathrm{O}_{3}$ and $\mathrm{ZnO}$ depletes electrons in $\mathrm{ZnO}$ and moves the conduction band of $\mathrm{CdS}$ upward compared to the bottom cell with an ohmic contact (Fig. 7b). This shift in the conduction band of CdS blocks electron transport at high forward bias and degrades the FF. A graded $\operatorname{In}_{2} \mathrm{O}_{3^{-}}$ $\mathrm{ZnO}$ layer between $\mathrm{In}_{2} \mathrm{O}_{3}$ to $\mathrm{ZnO}$ restores the efficiency to $6.65 \%$, the $\mathrm{J}_{\mathrm{SC}}$ to $18.7 \mathrm{~mA} / \mathrm{cm}^{2}$ and the fill factor to $75.1 \%$.

\section{CGS/CIS Tandem solar cell}

Fig. 8a shows the structure and band diagram for an optimized CGS/CIS tandem solar cell. The design shown in Fig. 8a incorporates the lessons from previous sections. Specifically, the top solar cell is comprised of a $1.6 \mu \mathrm{m}$ thick p-type CGS absorber with $\mathrm{ZnO}: \mathrm{Al} / \mathrm{ZnO}$ window 
layers, a CdS buffer layer and a $\mathrm{MoSe}_{2}$ contact layer. The bottom solar cell is comprised of a 2.0 $\mu \mathrm{m}$ thick p-type CIS absorber with a $\mathrm{ZnO}$ window layer and a $\mathrm{CdS}$ buffer layer. The $\mathrm{Cu}_{2} \mathrm{O}-\mathrm{In}_{2} \mathrm{O}_{3}$ broken-gap heterojunction is used to connect the top and bottom solar cells in series. A NiO buffer layer is used in the top cell between the $\mathrm{MoSe}_{2}$ and the $\mathrm{Cu}_{2} \mathrm{O}$ layers. Similarly, a graded $\mathrm{In}_{2} \mathrm{O}_{3}-\mathrm{ZnO}$ layer is inserted in the bottom cell between the $\operatorname{In}_{2} \mathrm{O}_{3}$ and $\mathrm{ZnO}$ layers. The band diagram at thermal equilibrium is shown on the right of Fig. 8a.

The performance of the CGS/CIS tandem solar cell is shown in Table 4 and Fig. 8a. Fig. $8 \mathrm{~b}$ shows the I-V characteristics of the top, bottom, and tandem solar cells. With a p- $\mathrm{Cu}_{2} \mathrm{O} / \mathrm{n}-$ $\mathrm{In}_{2} \mathrm{O}_{3}$ broken-gap heterojunction, the tandem CGS/CIS solar cell works successfully. The efficiency of the tandem solar cell is $24.1 \%$ while the efficiencies of the top and bottom cells are $17.5 \%$ and $6.7 \%$ respectively. The $\mathrm{V}_{\text {oc }}$ of the tandem device $(1.62 \mathrm{~V})$ is equal to the sum of the $\mathrm{V}_{\mathrm{oc}}$ for the top and bottom PV cells $(1.14 \mathrm{~V}$, and $0.47 \mathrm{~V}$, respectively). Due to current continuity, the $\mathrm{J}_{\mathrm{SC}}$ of a tandem cell is limited by lowest value of the two cells. For this device, $\mathrm{J}_{\mathrm{SC}}$ is 18.5 $\mathrm{mA} / \mathrm{cm}^{2}$, close to that of the top cell. Further structure optimization could be done to increase the current generated by the top cell thereby improving the overall efficiency. The FF of the tandem PV cells is substantially lower than that for the top cell (82.9\%). Due to the narrower bandgap of CIS compared to CIGS, a higher energy barrier forms at the CdS/CIS interface. This barrier impedes electron transport, reducing the FF of the bottom cell to $75.1 \%$ (Fig. 8b). The FF of the tandem cell is determined by the sum of FFs of top and bottom solar cells weighted by efficiency. Thus it becomes $80.5 \%$. The efficiency of a tandem solar cell is the sum of the efficiencies of top and bottom solar cells. The efficiencies of top and bottom cell in tandem solar cell are similar to the results of single solar cells when one takes into account screening by top cell. The ideal maximum efficiency of a CGS/CIS tandem solar cells is $25.3 \%$, the sum of the top and bottom 
solar cells with ohmic contacts. With $\mathrm{p}-\mathrm{Cu}_{2} \mathrm{O} / \mathrm{n}-\mathrm{In}_{2} \mathrm{O}_{3}$ broken-gap heterojunction, the efficiency of CGS/CIS tandem cell is $24.1 \%$ in this work. This efficiency degradation is mainly due to the energy barrier between the top cell and $\mathrm{p}-\mathrm{Cu}_{2} \mathrm{O}$. New process techniques such as compositional grading can reduce this barrier and improve the efficiency to a value close to the ideal case. The broken-gap heterojunction is a promising tunnel junction candidate for connecting top and bottom solar cells in a multi-junction PV device without performance loss.

Finally, we note that the quoted maximum efficiency, 25.3\%, is well below the ShockleyQueisser limit of $42.3 \%$ for an optimal cell [60]. The value we predict is a strong function of the assumptions. Our assumption of trap-free absorbers is clearly extremely optimistic. In state of the art CIGS, bulk traps do not significantly limit efficiency, however this is not true to CIS and CGS at this writing. Assuming these absorbers could be developed, further improvements could be made to approach this limit. Here we assumed uniform composition and doping. The types of grading used in champion single junction CIGS devices would improve efficiency. The band offset barrier described above could be reduced by modifying the buffer layer composition. The layer thicknesses could be optimized. In particular, the buffer layer thicknesses chosen for this simulation will lead to significant absorption.

\section{Conclusion}

A broken-gap p-n heterojunction, where the conduction band edge of the n-type material is equal to or lower in energy than the valence band edge of the p-type material, is studied as a potential tunnel junction in CIGS-based tandem solar cells. The broken-gap junction has a low resistance and linear I-V characteristic in both forward and reverse bias. The effectiveness of a specific broken-gap heterojunction between p-type $\mathrm{Cu}_{2} \mathrm{O}$ and n-type $\operatorname{In}_{2} \mathrm{O}_{3}$ in a multi-junction 
solar cell was studied using numerical simulation with DESSIS, a commercially available device simulator. Carrier transport across the $\mathrm{p}-\mathrm{Cu}_{2} \mathrm{O} / \mathrm{n}-\mathrm{In}_{2} \mathrm{O}_{3}$ broken-gap heterojunction occurs by ballistic transport. The junction has linear I-V characteristics with a resistance much lower than conventional tunnel junctions even when $\mathrm{Cu}_{2} \mathrm{O}$ is only moderately $\left(2 \times 10^{17} \mathrm{~cm}^{-3}\right)$ doped. Junction properties were improved further by inserting buffer layers between the tunnel junction and the absorbers in both top and the bottom cells to minimize the energy barriers between the tunnel junction and the solar cells. With an optimized tunnel junction structure, the efficiency of a CGS/CIS tandem PV cells was $24.1 \%$ predicted. Importantly, there are no significant losses in efficiency due to the presence of the $\mathrm{p}-\mathrm{Cu}_{2} \mathrm{O} / \mathrm{n}-\mathrm{In}_{2} \mathrm{O}_{3}$ broken-gap junctions as compared to the total efficiency of separate bottom and top solar cells. Thus, a p-Cu $\mathrm{Cu}_{2} \mathrm{O} / \mathrm{n}-\mathrm{In}_{2} \mathrm{O}_{3}$ broken-gap tunnel junction is an attractive approach for connecting solar cells in polycrystalline CIGS-based multijunction PV devices. 


\section{Acknowledgements}

The authors are grateful to Dr. Sukgeun Choi at National Renewable Energy Laboratory for discussions. This work was partially supported by DOE grant DE-EE0005319 and also by IREE grant RL-0003-12. 


\section{Table captions}

Table 1 Physical properties of the materials used in the device simulations.

Table 2 The simulation results for the top solar cell shown in Fig. 6a with various different bottom contacts.

Table 3 The simulation results for the bottom solar cell shown in Fig. 7a with various different top contacts.

Table 4 The performance of the top, the bottom and the CGS/CIS tandem solar cells. 


\section{Figure captions}

Fig. 1. Band alignment of broken-gap heterojunctions.

Fig. 2. (a) The band diagram and (b) carrier concentrations for a $\mathrm{Cu}_{2} \mathrm{O} / \mathrm{In}_{2} \mathrm{O}_{3}$ broken-gap heterojunction near the band overlap region for different values of the band overlap $(\chi)$ between $0.0 \mathrm{eV}$ and $0.2 \mathrm{eV}$. In (a) the solid and dotted lines represent the valence and the conduction bands, respectively. In (b) the solid and dotted lines represent the hole and electron concentrations, respectively.

Fig. 3. Possible current transport mechanisms in broken-gap heterojunctions: (1) interband transition at the interface (2) drift-diffusion and (3) ballistic transport.

Fig. 4. Calculated I-V characteristics for (a) the interface-interband transition model and (b) the ballistic transport model for different values of the band overlap $(\chi)$ between 0.0 $\mathrm{eV}$ and $0.2 \mathrm{eV}$.

Fig. 5. (a) $\mathrm{I}-\mathrm{V}$ characteristics of $10^{17} \mathrm{~cm}^{-3} \mathrm{p}-\mathrm{Cu}_{2} \mathrm{O}$ and $5 \times 10^{19} \mathrm{~cm}^{-3} \mathrm{n}-\mathrm{In}_{2} \mathrm{O}_{3}$ broken-gap heterojunction and pictorial band diagrams for each transport region, (b) band diagrams of $5 \times 10^{19} \mathrm{~cm}^{-3} \mathrm{Cu}_{2} \mathrm{O}$ with $10^{16}, 2 \times 10^{17}$ and $10^{18} \mathrm{~cm}^{-3} \operatorname{In}_{2} \mathrm{O}_{3}$.

Fig. 6. (a) Three top solar cell structures with different bottom contacts for comparison (1) an ohmic contact, (2) using $\mathrm{Cu}_{2} \mathrm{O}$ only, and (3) using $\mathrm{Cu}_{2} \mathrm{O}$ with a $\mathrm{NiO}$ buffer layer and comparison of calculated (b) valence band diagrams and (c) I-V characteristics of $\mathrm{CuGaSe}_{2}$ top solar cells with different bottom contacts.

Fig. 7. (a) Three bottom solar cell with top contact structures for comparison (1) an ohmic contact, (2) using $\mathrm{In}_{2} \mathrm{O}_{3}$ only, and (3) using $\mathrm{In}_{2} \mathrm{O}_{3}$ /graded $\mathrm{In}_{2} \mathrm{O}_{3}-\mathrm{ZnO}$ layer, 
comparison of calculated (b) conduction band diagrams and (c) I-V characteristics of $\mathrm{CuInSe}_{2}$ bottom solar cells with different top contacts.

Fig. 8. (a) The optimized tandem CGS/CIS solar cell structure and its band diagram and (b) I-V characteristics of just the CGS (top cell), just the CIS (bottom cell) and the tandem CGS/CIS tandem solar cell in (a). 


\section{Table 1}

Physical parameters for simulation.

\begin{tabular}{cccccc}
\hline \hline Material & $\begin{array}{c}\text { Dielectric } \\
\text { Constant }\end{array}$ & $\begin{array}{c}\text { Band gap } \\
{[\mathrm{eV}]}\end{array}$ & $\begin{array}{c}\text { Electron } \\
\text { Affinity }[\mathrm{eV}]\end{array}$ & $\begin{array}{c}\text { Mobility } \\
{\left[\mathrm{cm}^{2} / \mathrm{Vs}\right]}\end{array}$ & $\begin{array}{c}\text { Effective } \\
\text { Tunneling } \\
\text { mass }\end{array}$ \\
\hline $\mathrm{CGS}$ & 10.07 & 1.68 & 4.0 & $\mathrm{~N}: 100, \mathrm{P}: 45$ & \\
$\mathrm{MoSe}_{2}$ & 18.0 & 1.2 & 4.4 & $\mathrm{~N}: 45, \mathrm{P}: 15$ & \\
$\mathrm{NiO}$ & 11.9 & 3.6 & 1.6 & $\mathrm{~N}: 45, \mathrm{P}: 2$ & \\
$\mathrm{Cu}_{2} \mathrm{O}$ & 7.11 & 2.1 & 3.0 & $\mathrm{~N}: 45, \mathrm{P}: 15$ & $\mathrm{~m}_{\mathrm{h}}: 0.84[61]$ \\
$\mathrm{In}_{2} \mathrm{O} 3$ & 3.95 & 3.5 & 5.1 & $\mathrm{~N}: 45, \mathrm{P}: 15$ & $\mathrm{~m}_{\mathrm{e}}: 0.35[62]$ \\
$\mathrm{ZnO}$ & 7.8 & 3.441 & 4.5 & $\mathrm{~N}: 45, \mathrm{P}: 15$ & \\
$\mathrm{IZO}$ & $3.95-7.8$ & 3.5 & $5.0-4.5$ & $\mathrm{~N}: 45, \mathrm{P}: 15$ & \\
\hline \hline
\end{tabular}




\section{Table 2}

The simulation results of top PV cells shown in Fig. 5a with various different top contacts.

\begin{tabular}{|c|c|c|c|c|}
\hline & & Reference & BGJ & Buffer/BGJ \\
\hline \multirow{7}{*}{ Structure } & \multirow{5}{*}{ Top Cell } & \multicolumn{3}{|c|}{$\mathrm{ZnO}: \mathrm{Al}$, n-type, $1 \times 10^{19}, 150 \mathrm{~nm}$} \\
\hline & & \multicolumn{3}{|c|}{ ZnO, n-type, $1 \times 10^{17}, 100$ nm } \\
\hline & & \multicolumn{3}{|c|}{$\mathrm{CdS}$, n-type, $5 \times 10^{15}, 70 \mathrm{~nm}$} \\
\hline & & \multicolumn{3}{|c|}{$\mathrm{CuGaSe}_{2}$, p-type, $1 \times 10^{16}, 1.6 \mu \mathrm{m}$} \\
\hline & & \multicolumn{3}{|c|}{$\mathrm{MoSe}_{2}$, p-type, $1 \times 10^{18}, 10 \mathrm{~nm}$} \\
\hline & \multirow{2}{*}{$\begin{array}{l}\text { Broken-gap } \\
\text { junction }\end{array}$} & \multirow{2}{*}{$\begin{array}{l}\text { Ohmic } \\
\text { Contact }\end{array}$} & \multirow{2}{*}{$\begin{array}{c}\mathrm{Cu}_{2} \mathrm{O}, 1.5 \times 10^{19} \\
100 \mathrm{~nm}\end{array}$} & $\mathrm{NiO}, 1 \times 10^{18}, 50 \mathrm{~nm}$ \\
\hline & & & & $\mathrm{Cu}_{2} \mathrm{O}, 1.5 \times 10^{19}, 50 \mathrm{~nm}$ \\
\hline \multirow{4}{*}{ Performance } & Efficiency [\%] & 18.66 & 16.99 & 17.90 \\
\hline & $\mathrm{V}_{\mathrm{oc}}[\mathrm{V}]$ & 1.154 & 1.134 & 1.144 \\
\hline & $\mathrm{J}_{\mathrm{SC}}\left[\mathrm{mA} / \mathrm{cm}^{2}\right]$ & 18.77 & 17.97 & 18.44 \\
\hline & $\mathrm{FF}[\%]$ & 86.15 & 83.34 & 84.86 \\
\hline
\end{tabular}




\section{Table 3}

The simulation results of bottom PV cells shown in Fig. 6a with various different top contacts.

\begin{tabular}{|c|c|c|c|c|c|c|}
\hline & & \multicolumn{2}{|c|}{ Reference } & BGJ & \multicolumn{2}{|c|}{ Buffer/BGJ } \\
\hline \multirow{5}{*}{ Structure } & \multirow{2}{*}{$\begin{array}{c}\text { Broken-gap } \\
\text { junction }\end{array}$} & \multirow{2}{*}{\multicolumn{2}{|c|}{$\begin{array}{l}\text { Ohmic } \\
\text { Contact }\end{array}$}} & \multirow{2}{*}{$\begin{array}{c}\mathrm{In}_{2} \mathrm{O}_{3}, 1 \times 10^{19} \\
100 \mathrm{~nm}\end{array}$} & \multirow{2}{*}{\multicolumn{2}{|c|}{$\frac{\mathrm{In}_{2} \mathrm{O}_{3}, 1 \times 10^{19}, 50 \mathrm{~nm}}{\mathrm{IZO}, 1 \times 10^{19}, 50 \mathrm{~nm}}$}} \\
\hline & & & & & & \\
\hline & \multirow{3}{*}{$\begin{array}{c}\text { Bottom } \\
\text { Cell }\end{array}$} & \multicolumn{5}{|c|}{$\mathrm{ZnO}$, n-type, $1 \times 10^{17}, 100 \mathrm{~nm}$} \\
\hline & & \multicolumn{5}{|c|}{ CdS, n-type, $5 \times 10^{15}, 70 \mathrm{~nm}$} \\
\hline & & \multicolumn{5}{|c|}{$\mathrm{CuInSe}_{2}$, p-type, $1 \times 10^{16}, 2.0 \mu \mathrm{m}$} \\
\hline \multirow{5}{*}{ Performance } & Intensity & 1 Sun & \multicolumn{4}{|c|}{ Top PV cell screened } \\
\hline & $\begin{array}{c}\text { Efficiency } \\
{[\%]}\end{array}$ & 14.26 & 6.67 & 5.77 & & 6.65 \\
\hline & $\mathrm{V}_{\mathrm{oc}}[\mathrm{V}]$ & 0.493 & 0.473 & 0.474 & & 0.473 \\
\hline & $\begin{array}{c}\mathrm{J}_{\mathrm{SC}} \\
{\left[\mathrm{mA} / \mathrm{cm}^{2}\right]}\end{array}$ & 38.52 & 18.76 & 17.86 & & 18.70 \\
\hline & $\mathrm{FF}[\%]$ & 75.10 & 75.13 & 68.18 & & 75.12 \\
\hline
\end{tabular}




\section{Table 4}

The performance of top, bottom and CGS/CIS tandem PV cells.

\begin{tabular}{cccc}
\hline \hline & Top Cell & Bottom Cell & Tandem Cell \\
\hline Efficiency [\%] & 17.5 & 6.47 & 24.1 \\
$\mathrm{~V}_{\mathrm{oc}}[\mathrm{V}]$ & 1.14 & 0.473 & 1.62 \\
$\mathrm{~J}_{\mathrm{SC}}\left[\mathrm{mA} / \mathrm{cm}^{2}\right]$ & 18.5 & 18.5 & 18.5 \\
FF $[\%]$ & 82.9 & 73.9 & 80.5 \\
\hline \hline
\end{tabular}




\section{References}

[1] M. A. Green, Third generation photovoltaics: ultra-high conversion efficiency at low cost, Progress in Photovoltaics: Research and Applications 9 (2001) 123-135.

[2] R. M. Swanson, Photovoltaics power up, Science 324 (2009) 891-892.

[3] First Solar Annual Report: Phoenix, 2011.

[4] I. Repins, M. A. Contreras, B. Egaas, C. DeHart, J. Scharf, C. L. Perkins, B. To, R Noufi, $19.9 \%$-efficient $\mathrm{ZnO} / \mathrm{CdS} / \mathrm{CuInGaSe}_{2}$ solar cell with $81.2 \%$ fill factor, Progress in Photovoltaics: Research and Applications 16 (2008) 235-239.

[5] W. Shockley, H. J. Queisser, Detailed Balance Limit of Efficiency of p-n Junction Solar Cells, Journal of Applied Physics 32 (1961) 510-519.

[6] M. A. Green, K. Emery, Y. Hishikawa, W. Warta, E. D. Dunlop, Solar cell efficiency tables (version 42), Progress in Photovoltaics: Research and Applications 21 (2013) 827-837.

[7] H. Cotal, C. Fetzer, J. Boisvert, G. Kinsey, R. King, P. Hebert, H. Yoon, N. Karam, III-V multijunction solar cells for concentrating photovoltaics, Energy \& Environmental Science 2 (2009) 174-192.

[8] S. M. Sze, K. K. Ng, Physics of Semiconductor Devices 3rd ed., Wiley, New York, 2007.

[9] T. I. Kamins, J. Manoliu, R. N. Tucker, Diffusion of impurities in polycrystalline silicon, Journal of Applied Physics 43 (1972) 83-91.

[10] K. Mochizuki, T. Nakamura, Comparison of Be and C diffusion in heavily doped polycrystalline GaAs, Applied Physics Letters 65 (1994) 2066-2068.

[11] Y. Zhao, C. Persson, S. Lany, A. Zunger, Why can $\mathrm{CuInSe}_{2}$ be readily equilibrium-doped ntype but the wider-gap $\mathrm{CuGaSe}_{2}$ cannot?, Applied Physics Letters 85 (2004) 5860-5862.

[12] S. B. Zhang, S. Wei, A. Zunger, A phenomenological model for systematization and prediction of doping limits in II-VI and I-III-VI2 compounds, Journal of Applied Physics 83 (1998) 3192-3196.

[13] D. L. Young, J. Abushama, R. Noufi, X. Li, J. Keane, T. A. Gessert, J. S. Ward, M. Contreras , M. Symko-Davies, T. J. Coutts, A new thin-film $\mathrm{CuGaSe}_{2} / \mathrm{Cu}(\mathrm{In}, \mathrm{Ga}) \mathrm{Se}_{2}$ bifacial, tandem solar cell with both junctions formed simultaneously, Proceedings of 29th IEEE Photovoltaic Specialists Conference, 2002, pp. 608-611.

[14] M. Symko-Davies, Status of high performance PV: polycrystalline thin-film tandems. Proceedings of 31th IEEE Photovoltaic Specialists Conference, 2005, pp. 410-413.

[15] P. J. Rostan, J. Mattheis, G. Bilger, U. Rau, J. H. Werner, Formation of transparent and ohmic $\mathrm{ZnO}: \mathrm{Al} / \mathrm{MoSe}_{2}$ contacts for bifacial $\mathrm{Cu}(\mathrm{In}, \mathrm{Ga}) \mathrm{Se}_{2}$ solar cells and tandem structures, Thin Solid Films 480-481 (2005) 67-70.

[16] D. J. L. Brémaud, Investigation and development of CIGS solar cells on flexible substrates and with alternative electrical back contacts, Zurich, 2009. 
17] T. Nakada, Y. Hirabayashi, T. Tokado, D. Ohmori, T. Mise, Novel device structure for $\mathrm{Cu}(\mathrm{In}, \mathrm{Ga}) \mathrm{Se}_{2}$ thin film solar cells using transparent conducting oxide back and front contacts, Solar Cells 77 (2004) 739-747.

[18] Forrest Johnson, Sang Ho Song, Richard Liptak, and Stephen A. Campbell, Sputtering of Metal Oxide Tunnel Junctions for Tandem Solar Cells, Proceedings of the 39th IEEE Photovoltaic Specialist Conference (2013).

[19] J.J. Rembold, T.W. Curtis, J.T. Heath, D. L. Young, S.W. Johnston, W. N. Shafarman, Electronic defects and device performance in $\mathrm{CuGaSe} 2$ solar cells, Proceedings Materials Research Society Symposium. Volume 1012. Thin-Film Compound Semiconductor Photovoltaics - 2007, p 425-30, April 2007.

[20] G. Hanna, A. Jasenek, U. Rau, H. W. Schock, Influence of the Ga-content on the bulk defect densities of $\mathrm{Cu}(\mathrm{In}, \mathrm{Ga}) \mathrm{Se}_{2}$, Thin Solid Films 387 (2001) 71-73.

[21] V. Nadenau, U. Rau, A. Jasenek, H. W. Schock. Electronic properties of $\mathrm{CuGaSe}_{2}$-based heterojunction solar cells. Part I. Transport analysis, Journal of Applied Physics 87 (2000) 584-593.

[22] M. A. Contreras Prog. PV Res. App., 20 (2012) 843.

[23] Jian V. Li, S. Grover, M. A. Contreras, K. Ramanathan, D. Kuciauskas, and R. Noufi "A recombination analysis of $\mathrm{Cu}(\mathrm{In}, \mathrm{Ga}) \mathrm{Se}_{2}$ solar cells with low and high $\mathrm{Ga}$ compositions", Solar Energy Materials \& Solar Cells 124 (2014) 143-149.

[24] S-Y Park, E-W Lee, S-H Lee, S-W Park, W. K. Kim, S. H. Lee, W-G Lee, B. J. Lee, H. K. $\mathrm{Bae}, \mathrm{J}$. H. Yoo, and C-W Jeon, Investigation of $\mathrm{ZnO} / \mathrm{CdS} / \mathrm{CuInxGa1-xSe2}$ interface reaction by using hot-stage TEM, Current Applied Physics, 10,(2010) S399-S401.

[25] S. Kijima and T. Nakada, High-Temperature Degradation Mechanism of Cu(In,Ga)Se2Based Thin Film Solar Cells, Applied Physics Express 1 (2008) 075002

[26] H. Sugimoto, High Efficiency and Large Volume Production of CIS-Based Modules, Proc. of the $40^{\text {th }}$ Photovoltaic Specialists Conference, Denver (2014).

[27] D. L. Young, Y. J. Keane, A. Duda, J. A. M. AbuShama, C. L. Perkins, M. Romero, R. Noufi , Improved performance in $\mathrm{ZnO} / \mathrm{CdS} / \mathrm{CuGaSe}_{2}$ thin-film solar cells, Progress in Photovoltaics: Research and Applications 11 (2003) 535-541.

[28] J. Song, S. S. Li, L. Chen, R. Noufi, T. J. Anderson, O. D. Crisalle, Investigation of CdZnS Buffer Layers on the Performance of CuInGaSe 2 and $\mathrm{CuGaSe}_{2}$ Solar Cells, Proceedings of 4th World Conference on Photovoltaic Energy Conversion (2006) 534-537.

[29] K. Nagaich, S. Campbell, E. S. Aydil, Wide band-gap CuIn ${ }_{1-X} \mathrm{Ga}_{X} \mathrm{Se}_{2}$ based chalcopyrite absorbers for tandem cell applications,Proceedings of 37th IEEE Photovoltaic Specialists Conference, (2011) 000425-9.

[30] P. Ersleva, G. M. Hanket, W. N. Shafarman, and D. J. Cohen, Characterizing the effects of silver alloying in chalcopyrite CIGS with junction capacitance methods, 2009 MRS Spring Meeting MRS Proceedings / Volume 1165 DOI: http://dx.doi.org/10.1557/PROC-1165-M0107. 
[31] S. Karthikeyan, M. Sibakoti, R. Liptak, S. H. Song, J. Abrahamson, E. S. Aydil and S. A. Campbell, Challenges in deposition of wide band gap copper indium aluminum gallium selenide (CIAGS) thin films for tandem solar cells, Proceedings of 40th IEEE Photovoltaic Specialist Conference, (2014).

[32] K. L Chopra, S. Major, D. K. Pandya, Transparent conductors-A status review, Thin Solid Films 102, 1983,pp. 1-46.

[33] T. Minami, New n-type transparent conducting oxide. MRS Bulletin 25 (2000) 38-44.

[34] C. G. Granqvis, Transparent conductors as solar energy materials: A panoramic review, Solar Energy Materials \& Solar Cells 91 (2007) 1529-1598.

[35] J. Robertson, S. J. Clark, Limits to doping in oxides, Physical Review B 83 (2011) 075205.

[36] A. Zunger, Practical doping principles, Applied Physics Letters 83 (2003) 57-59.

[37] H. Sakaki, L. L. Chang, R. Ludeke, C. Chang, G. A. Sai-Halasz, L. Esaki, $\operatorname{In}_{1-\mathrm{x}} \mathrm{Ga}_{\mathrm{x}} \mathrm{As}-$ $\mathrm{GaSb}_{1-y} \mathrm{As}_{\mathrm{y}}$ heterojunctions by molecular beam epitaxy, Applied Physics Letters 31 (1977) 211-213.

[38] G. J. Gualtieri, G. P. Schwartz, R. G. Nuzzo, R. J. Malik, J. F. Walker, Determination of the (100) InAs/GaSb heterojunction valenceband discontinuity by xray photoemission core level spectroscopy, Journal of Applied Physics 61 (1987) 5337-5341.

[39] M. P. Mikhailova, K. D. Moiseev, Y. P. Yakovlev, Interface-induced optical and transport phenomena in type II broken-gap single heterojunctions, Semiconductor Science and Technology 19 (2004) R109-R128.

[40] A. K. Srivastava, J. L. Zyskind, R. M. Lum, B. V. Dutt, J. K. Klingert, Electrical characteristics of InAsSb/GaSb heterojunctions, Applied Physics Letters 49 (1986) 41-43.

[41] K. Vizbaras, M. Törpe, S. Arafin, M. Amann, Ultra-low resistive GaSb/InAs tunnel junctions, Semiconductor Science and Technology 26 (2011) 075021.

[42] H. Tanakaa, T. Shimakawaa, T. Miyataa, H. Satob, T. Minami, Electrical and optical properties of TCO- $\mathrm{Cu}_{2} \mathrm{O}$ heterojunction devices, Thin Solid Films 469-470 (2004) 80-85.

[43] J. Deuermeier, J. Gassmann, J. Brötz, A. Klein, Reactive magnetron sputtering of $\mathrm{Cu}_{2} \mathrm{O}$ : Dependence on oxygen pressure and interface formation with indium tin oxide, Journal of Applied Physics 109 (2011) 113704.

[44] A. Facchetti, T. J. Marks. Transparent Electronics: From Synthesis to Applications, Wiley, New York, 2010.

[45] J. Song, S. S. Li, C. H. Huang, T. J. Anderson, O. D. Crisalle, Modeling and simulation of a $\mathrm{CuGaSe}_{2} / \mathrm{Cu}\left(\mathrm{In}_{1-\mathrm{x}}, \mathrm{Ga}_{\mathrm{x}}\right) \mathrm{Se}_{2}$ tandem solar cell, Proceedings of 3rd World Conference on Photovoltaic Energy Conversion, 2003, pp. 555-558.

[46] M. W. Wang, Novel CdSe-based PV structure for high efficiency CdSe/CIGS tandem solar cells, Proceedings of 34th IEEE Photovoltaic Specialists Conference, 2009, pp. 000480000493. 
[47] ISE DESSIS Manual Release: 9.5, Synopsys, Mountain View, 2004.

[48] R. L. Anderson, Experiments on Ge-GaAs heterojunctions, Solid State Electronics 5 (1962) 341-351.

[49] S. O. Koswatta, S. J. Koester, W. Haensch, On the possibility of obtaining MOSFET-like performance and sub-60-mV/dec swing in 1-D broken-gap tunnel transistors, IEEE Transactions on Electron Devices 57 (2010) 3222-3230.

[50] J. Knoch, J. Appenzeller. Modeling of high-performance p-Type III-V heterojunction tunnel FETs, IEEE Electron Device Letters 31 (2010) 305-307.

[51] H. Kroemer, W. Chien, J. S. Harris, D. D. Edwall, Measurement of isotype heterojunction barriers by CV profiling, Applied Physics Letters 36 (1980) 295-297.

[52] T. Tomizawa, Numerical simulation of submicron semiconductor devices, Artech house, Boston, 1993.

[53] S. H. Song, K. Nagaich, E. Aydil, R. Feist, R. Haley, and S. A. Campbell, Structure Optimization for a High Efficiency CIGS Solar Cell, Proceedings of the IEEE Photovoltaics Specialists Conference, Honolulu (2010).

[54] D. A. Collins, E. T. Yu, Y. Rajakarunanayake, J. R. Söderström, D. Z.-Y. Ting, D. H. Chow, T. C. McGill, Experimental observation of negative differential resistance from an InAs/GaSb interface, Applied Physics Letters 57 (1990) 683-685.

[55] A. Martí, G. L. Araújo, Limiting efficiencies for photovoltaic energy conversion in multigap systems, Solar Energy Materials \& Solar Cells 43 (1996) 203-222.

[56] A. Mallouky, J. C. Bernede. Characterization of $\mathrm{MoSe}_{2}$ Thin Films, Thin Solid Films 158 (1988) 285-498.

[57] M. Bär, S. Nishiwaki, L. Weinhardt, S. Pookpanratana, W. N. Shafarman, C. Heske, Electronic level alignment at the deeply buried absorber/Mo interface in chalcopyrite-based thin film solar cells, Applied Physics Letters 93 (2008) 042110.

[58] R. Pasquarelli, M. Van Hest, A. Miedaner, C. Curtis, J. Perkins, R. O'Hayre, D. Ginley, Solution deposition of amorphous IZO films by ultrasonic spray, 35th IEEE Photovoltaic Specialists Conference, PVSC 2010 p 2471-2473.

[59] A. O. Pudov, A. Kanevce, H. A. Al-Thani, J. R. Sites, F. S. Hasoon, Secondary barriers in $\mathrm{CdS}-\mathrm{CuIn}_{1-\mathrm{x}} \mathrm{Ga}_{\mathrm{x}} \mathrm{Se} 2$ solar cells, Journal of Applied Physics 97 (2005) 064901.

[60] Alexis De Vos, Detailed balance limit of the efficiency of tandem solar cells J. Phys. D: Appl. Phys., 13 (1980) 83946.

[61] A. G. Zhilich, J. Halpern, B. R. Zakharchenya, Magnetoabsorption Oscillations and the Zeeman Effect of Excitons for Forbidden Interband Transitions in $\mathrm{Cu}_{2} \mathrm{O}$ Crystals, Physical Review 188 (1969) 1294-1302.

[62] I. Hamberg, C. G. Granqvist, Evaporated Sndoped $\operatorname{In}_{2} \mathrm{O}_{3}$ films: Basic optical properties and applications to energy efficient windows, Journal of Applied Physics 60 (1986) R123-R159. 


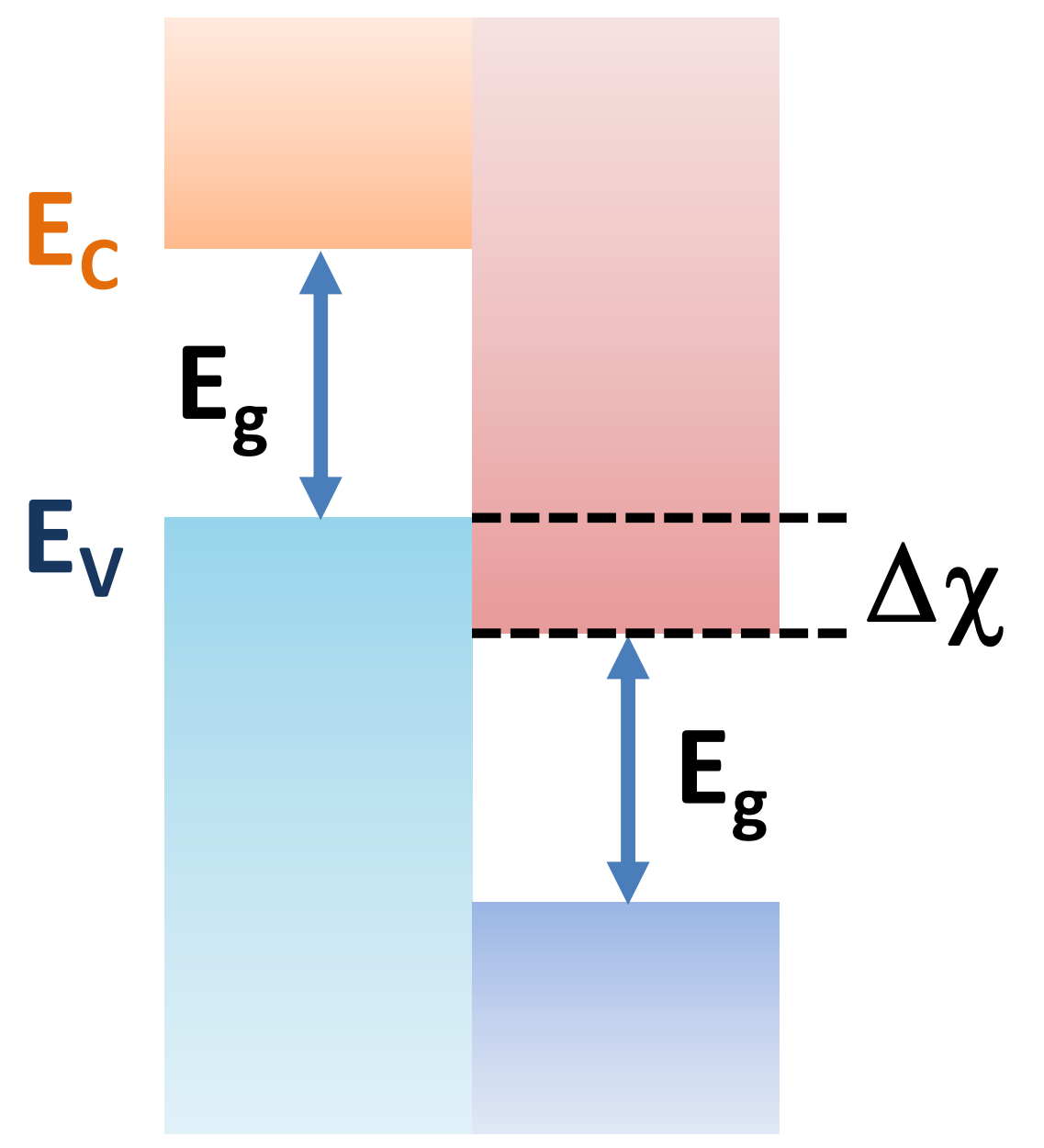




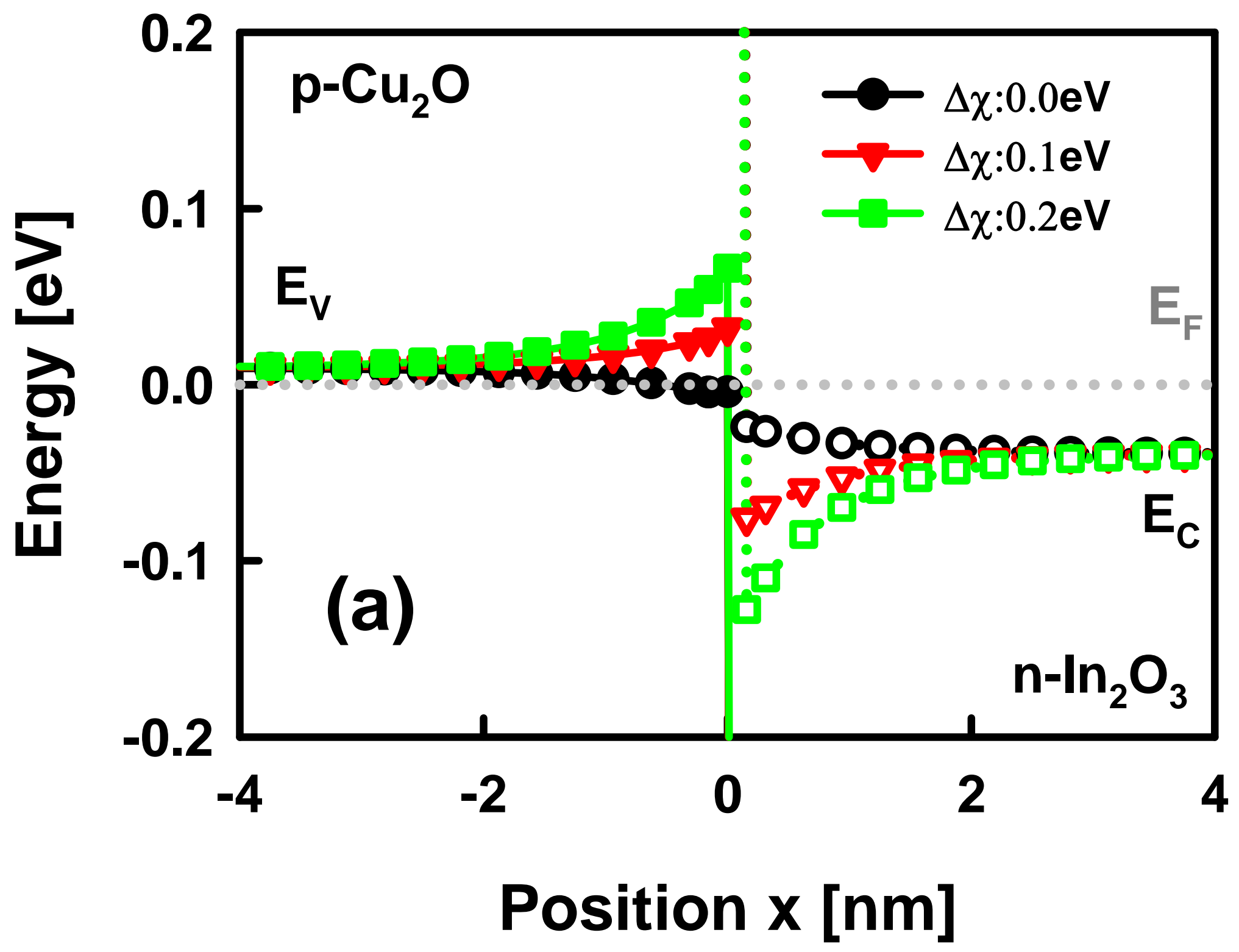




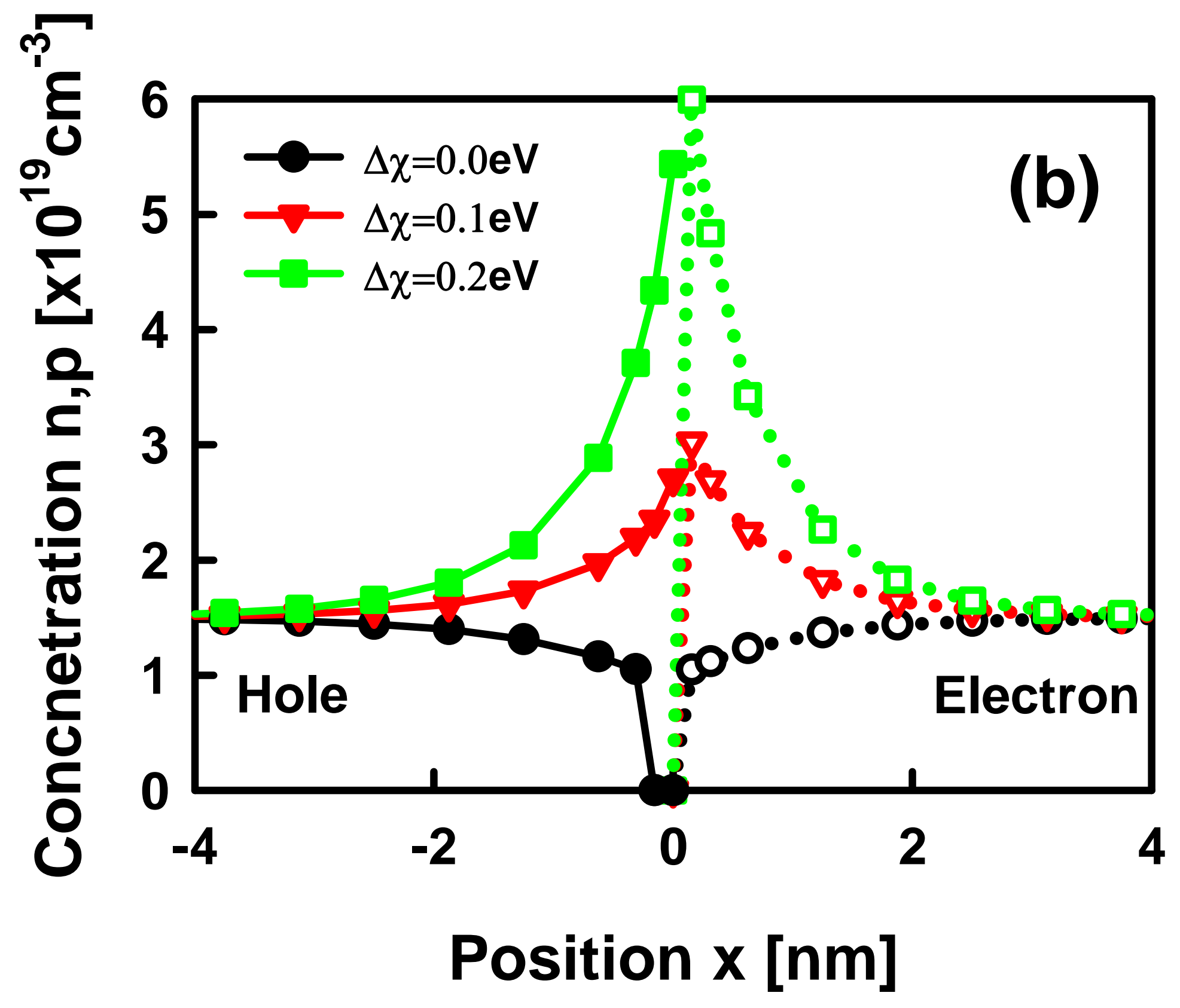




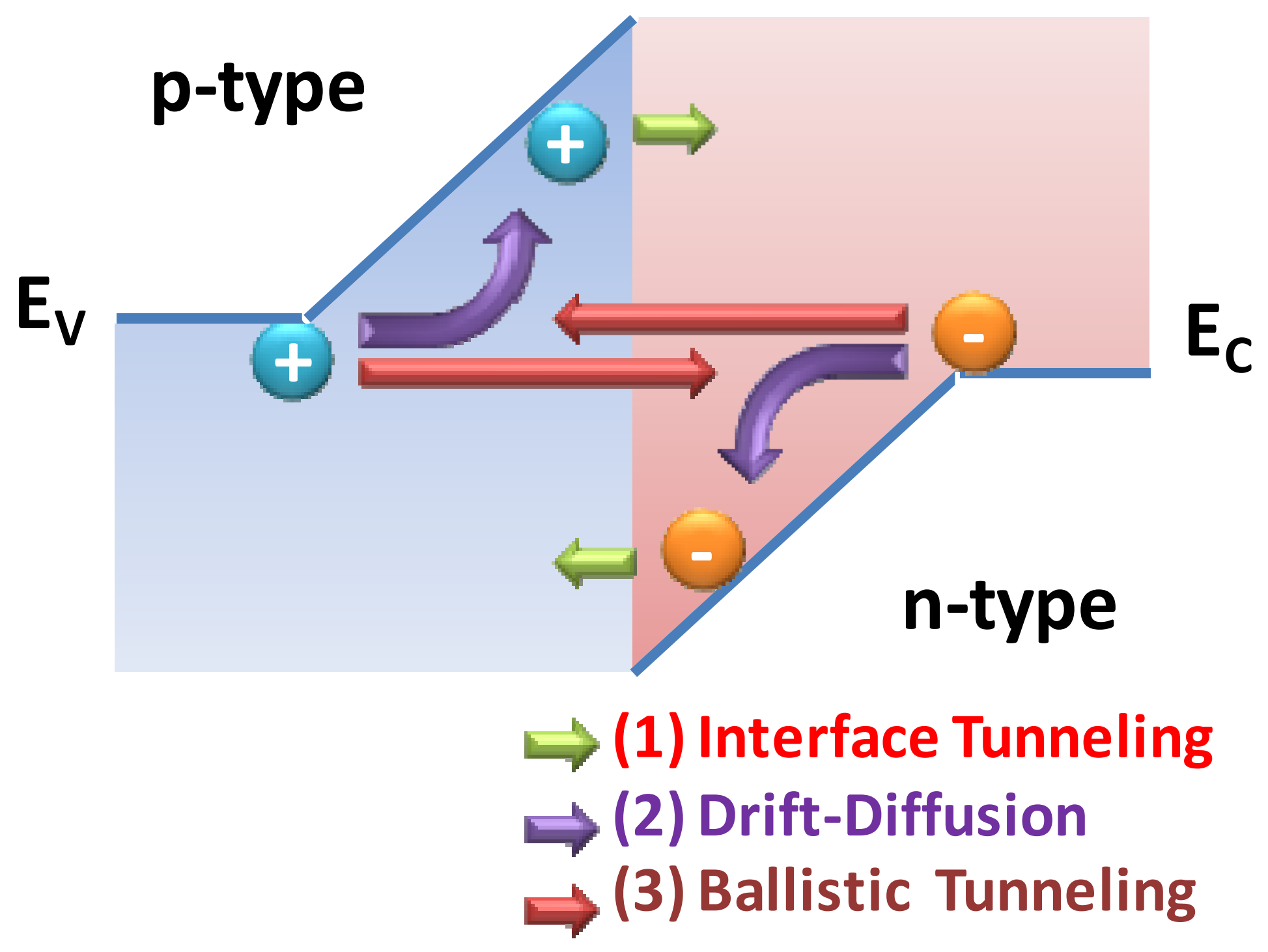




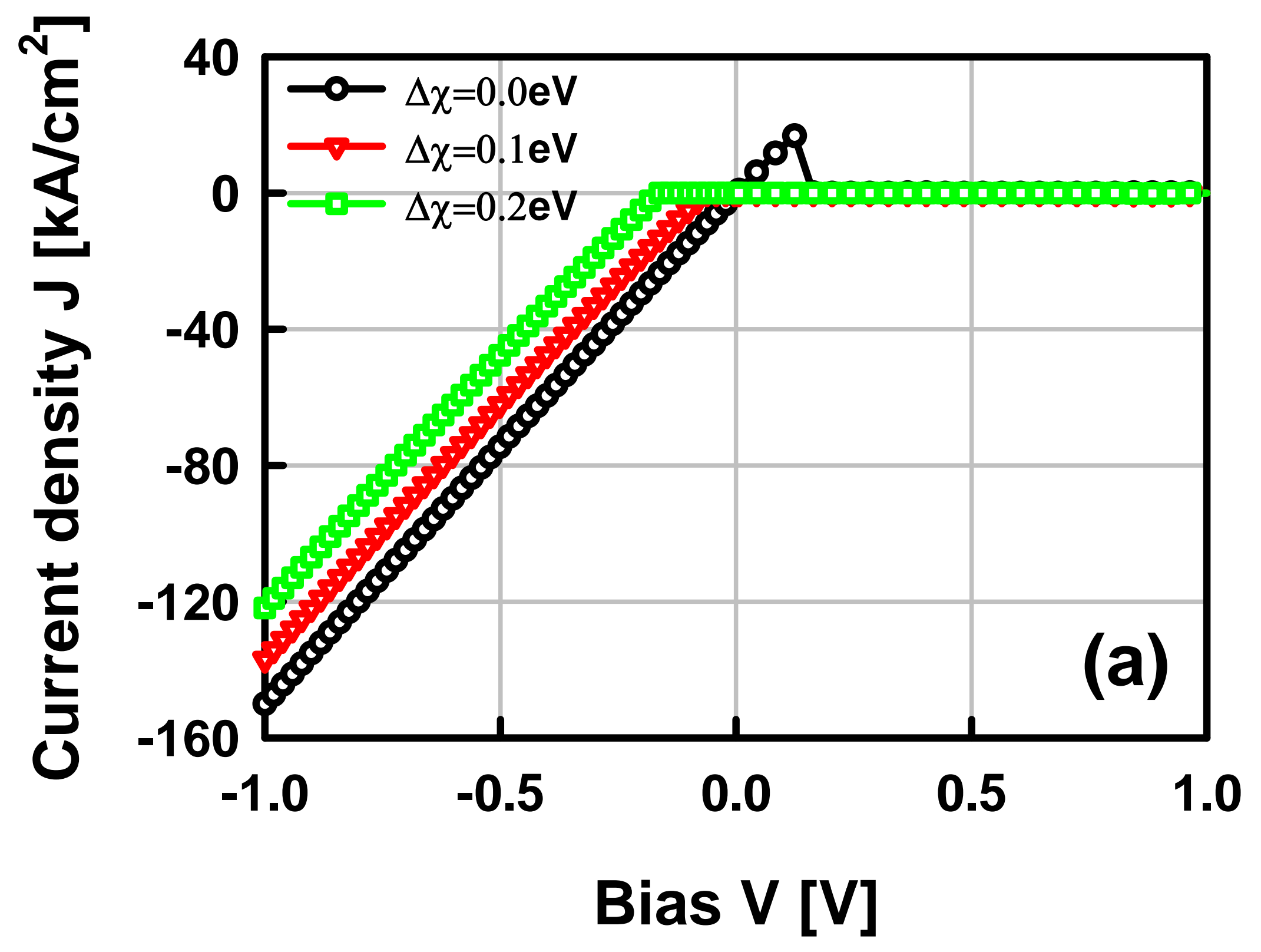




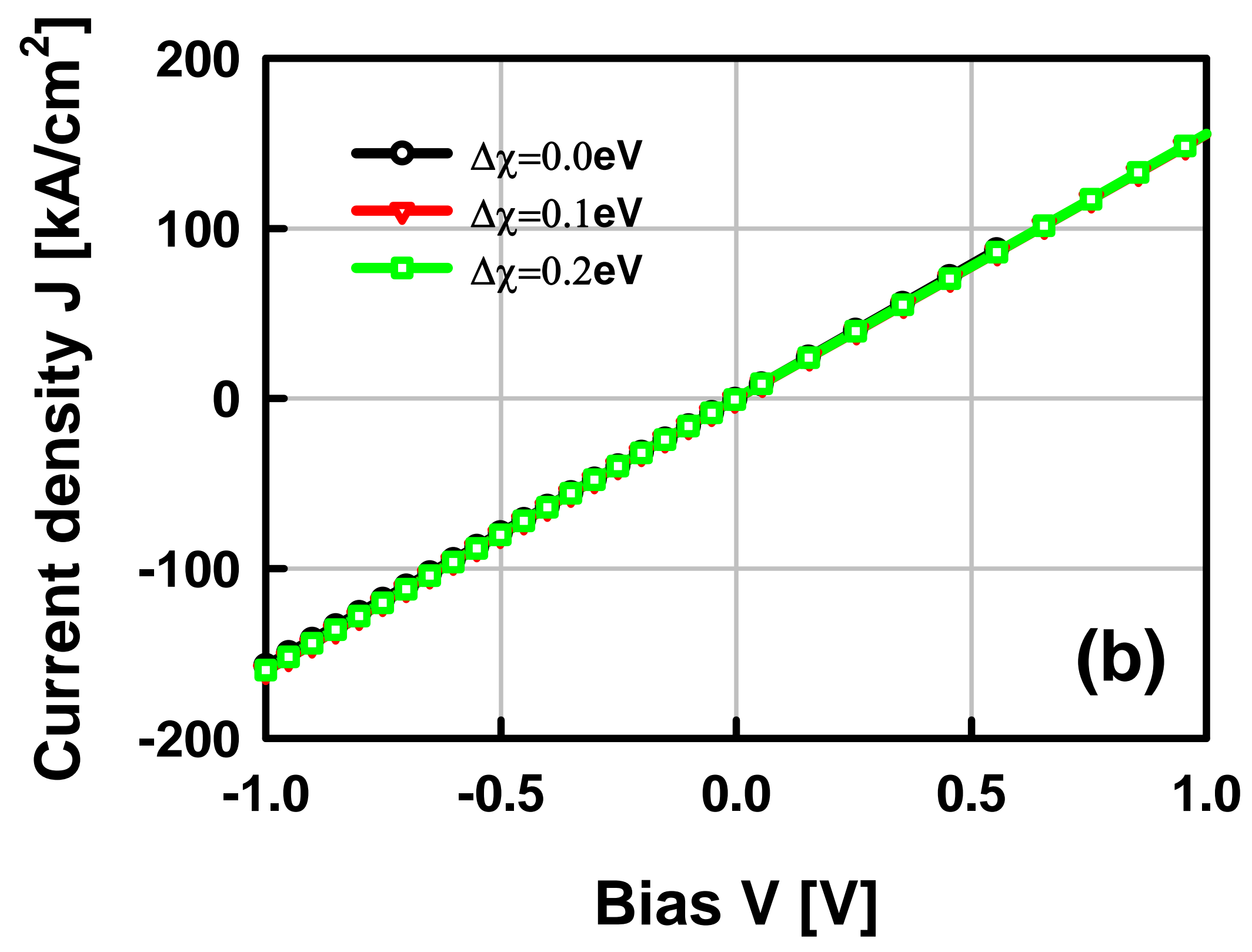




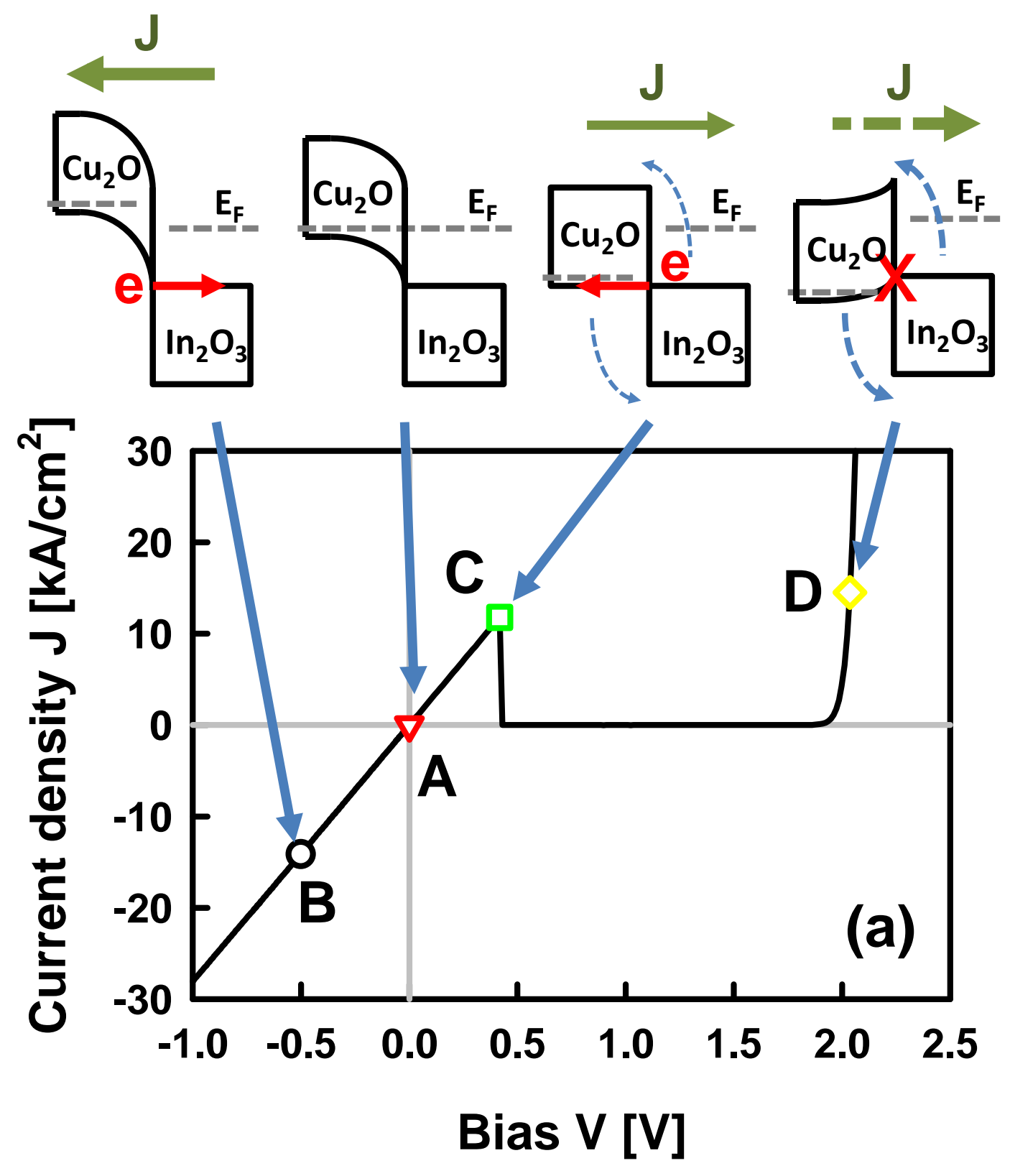




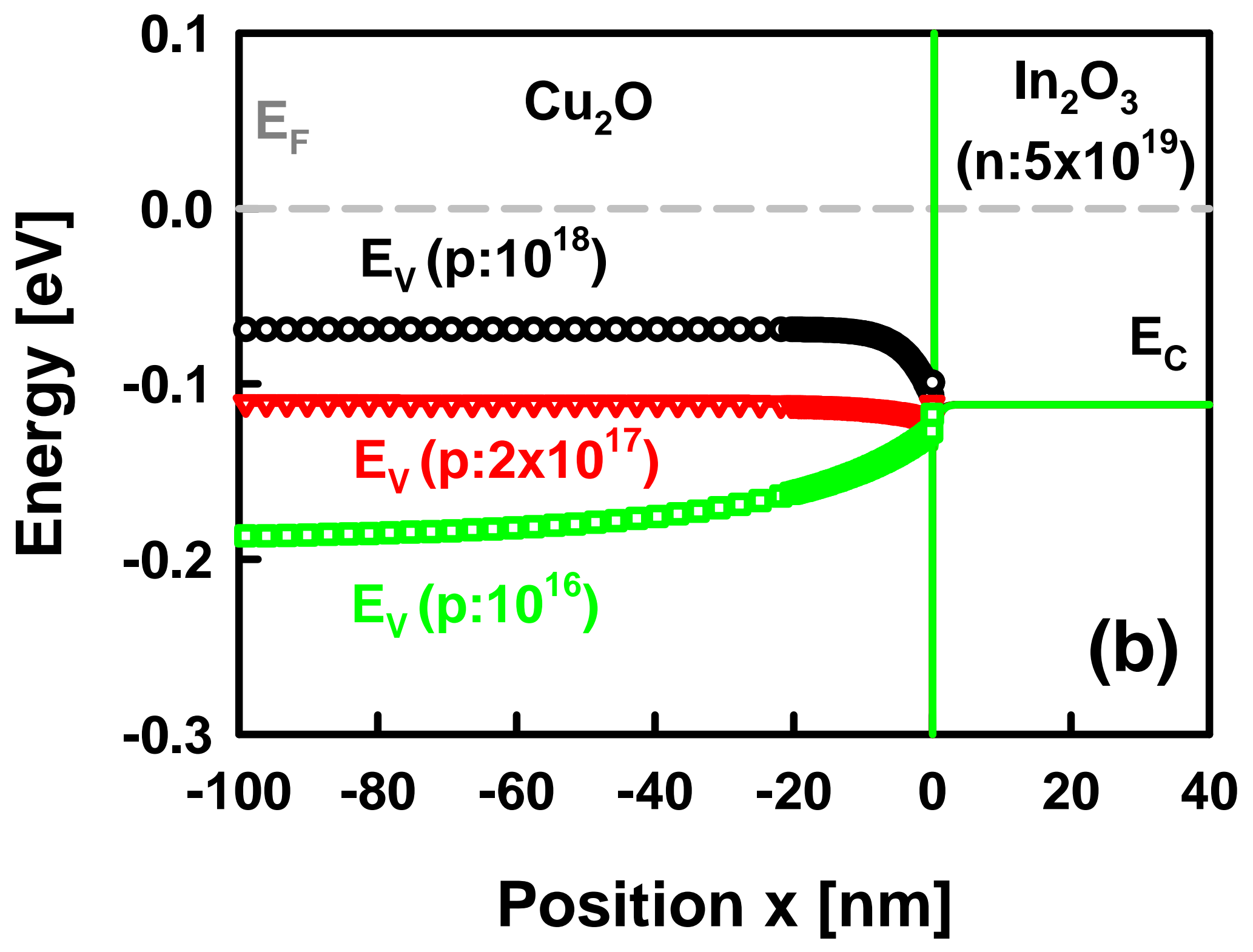


(1) Ohmic contact

\begin{tabular}{|c|}
\hline$Z n O: A l ~(n-1 e 19,150 \mathrm{~nm})$ \\
\hline ZnO (n-1e17, 100nm) \\
\hline CdS(n-5e15, 70nm) \\
\hline CGS (p-1e16, 1.6 $\mu \mathrm{m})$ \\
\hline $\operatorname{MoSe}_{2}(p-1 \mathrm{e} 18,10 \mathrm{~nm})$ \\
\hline
\end{tabular}

(a)
(2) $\mathrm{Cu}_{2} \mathrm{O}$

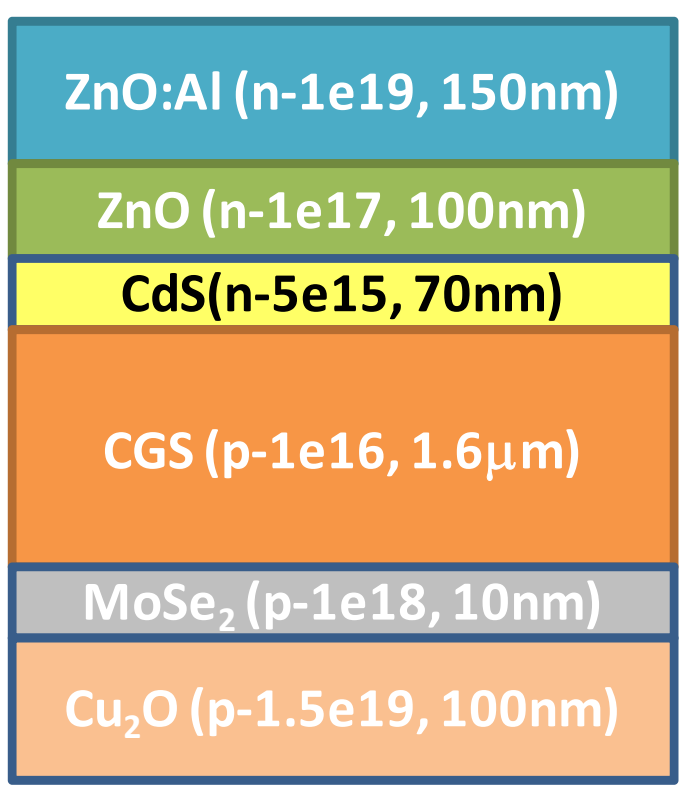

(3) $\mathrm{NiO} / \mathrm{Cu}_{2} \mathrm{O}$

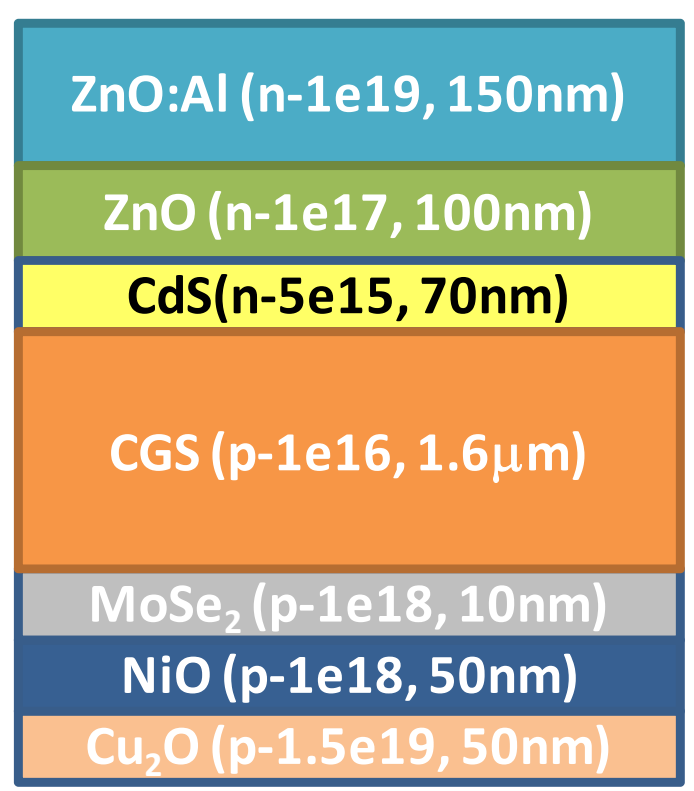




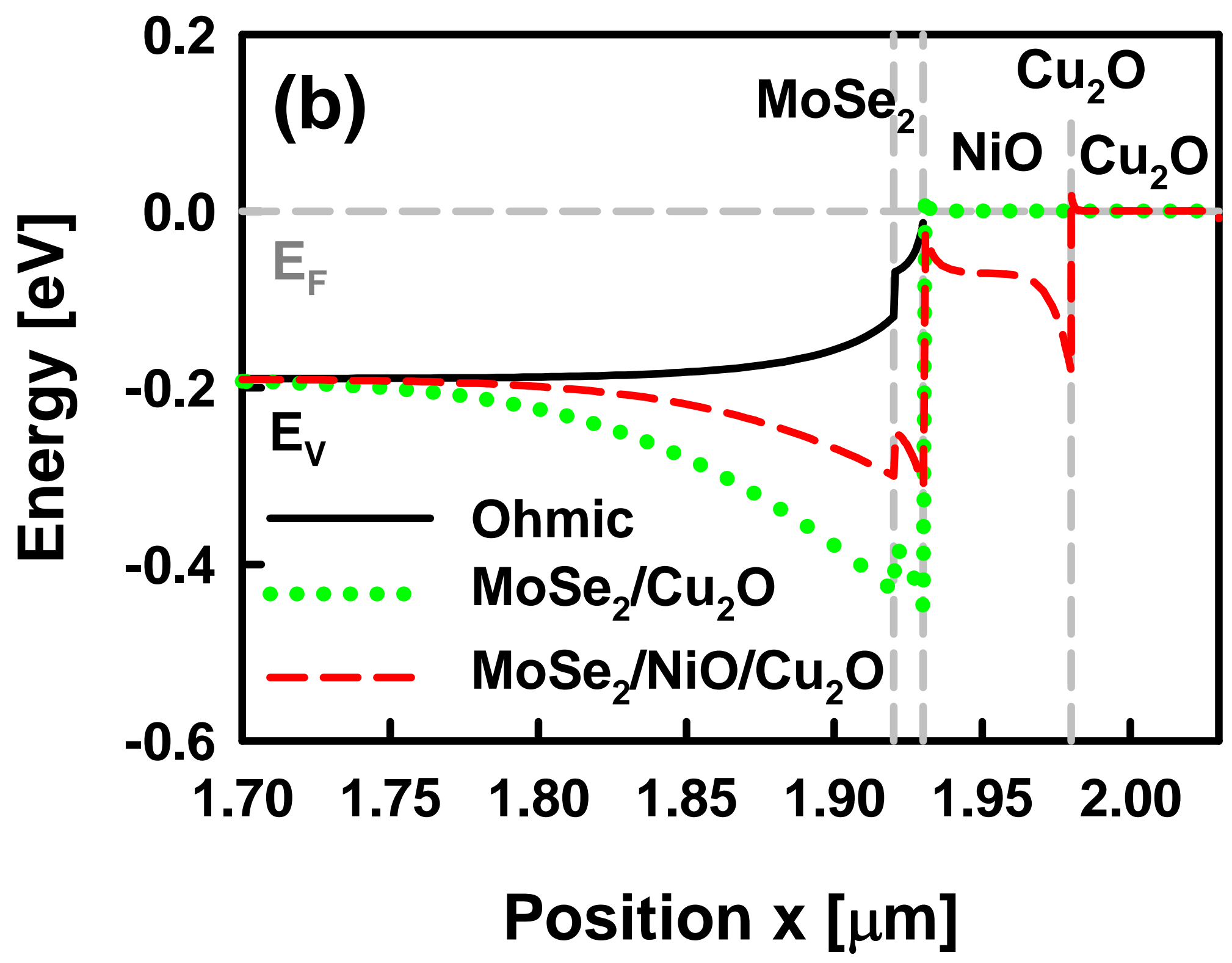




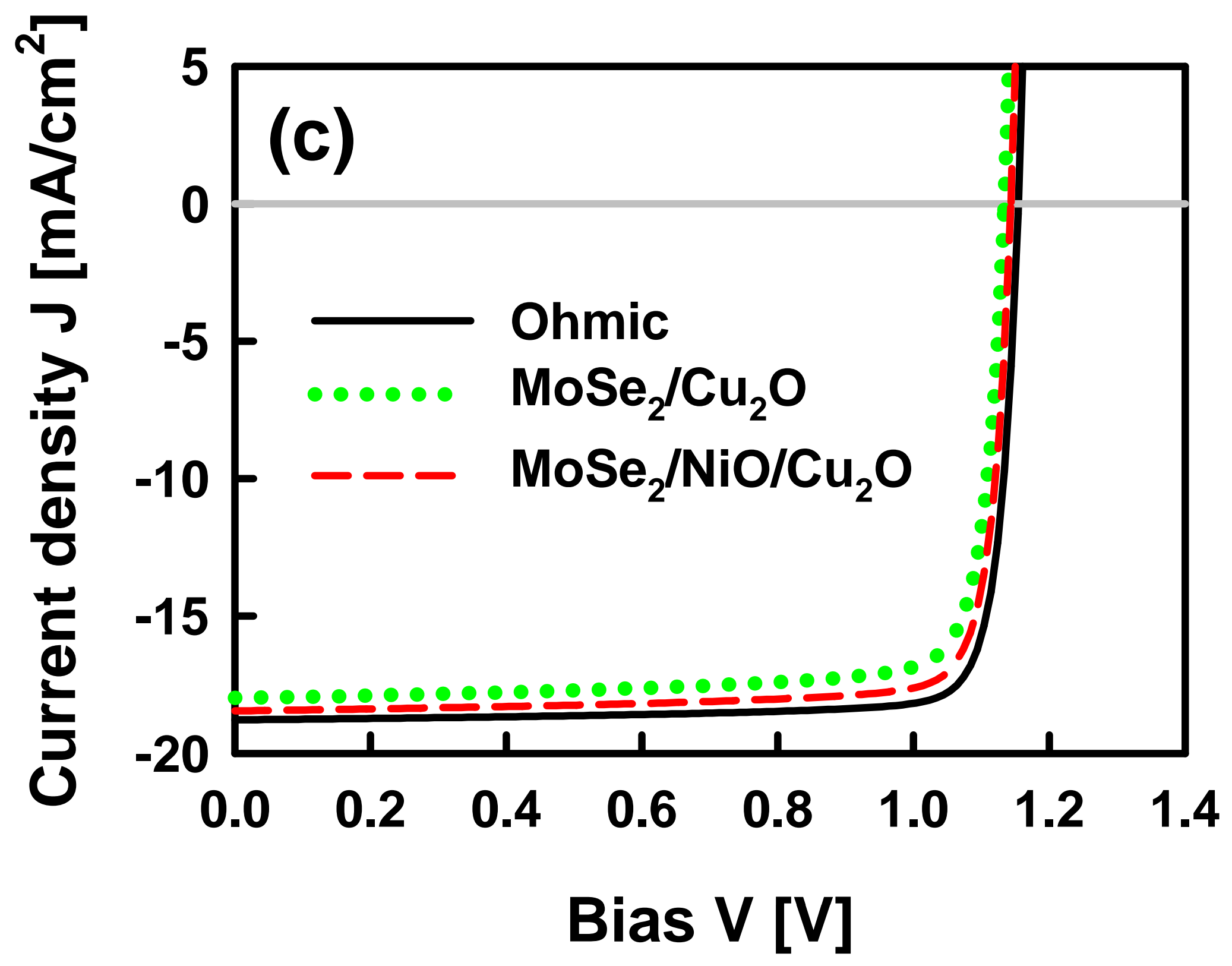


(a)

\section{(1) Ohmic contact}

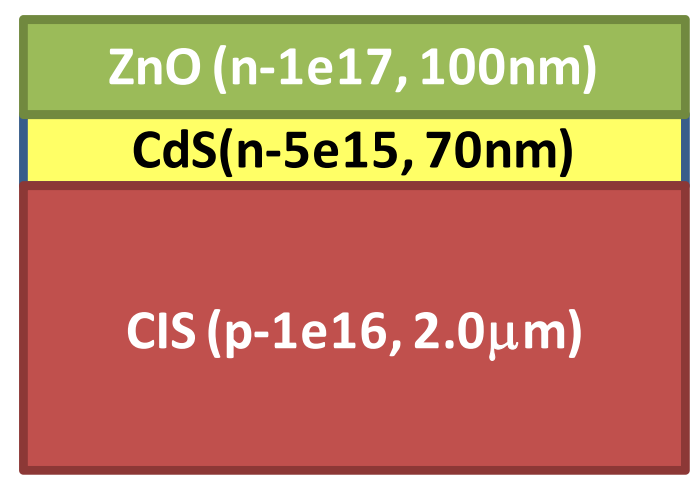

(2) $\ln _{2} \mathrm{O}_{3}$

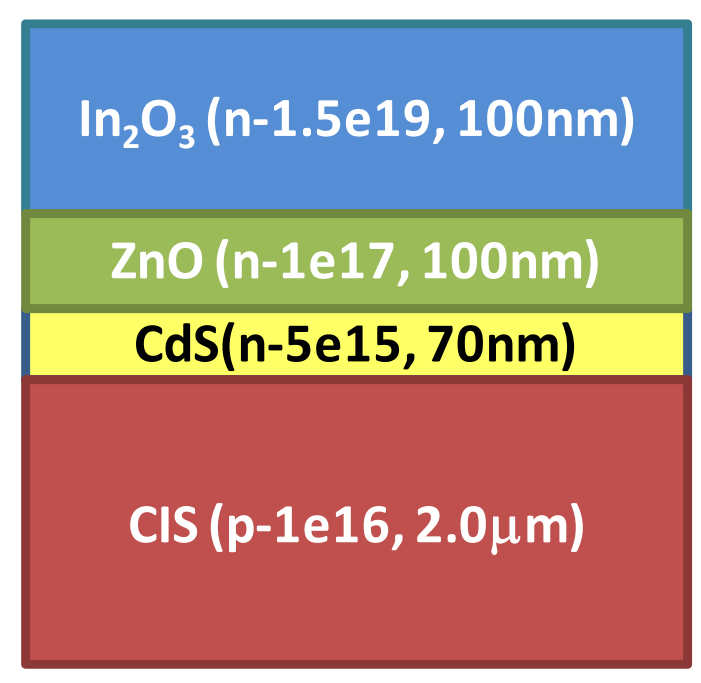

(3) $\ln _{2} \mathrm{O}_{3} /$ $\mathrm{In}_{2} \mathrm{O}_{3}-\mathrm{ZnO}$ grading

$\operatorname{In}_{2} \mathrm{O}_{3}(\mathrm{n}-1.5 \mathrm{e} 19,50 \mathrm{~nm})$
$\operatorname{In}_{2} \mathrm{O}_{3}-\mathrm{ZnO}(\mathrm{n}-1 \mathrm{e} 19,50 \mathrm{~nm})$
$\mathrm{ZnO}(\mathrm{n}-1 \mathrm{e} 17,100 \mathrm{~nm})$
$\mathrm{CdS}(\mathrm{n}-5 \mathrm{e} 15,70 \mathrm{~nm})$
$\mathrm{CIS}(\mathrm{p}-1 \mathrm{e} 16,2.0 \mu \mathrm{m})$




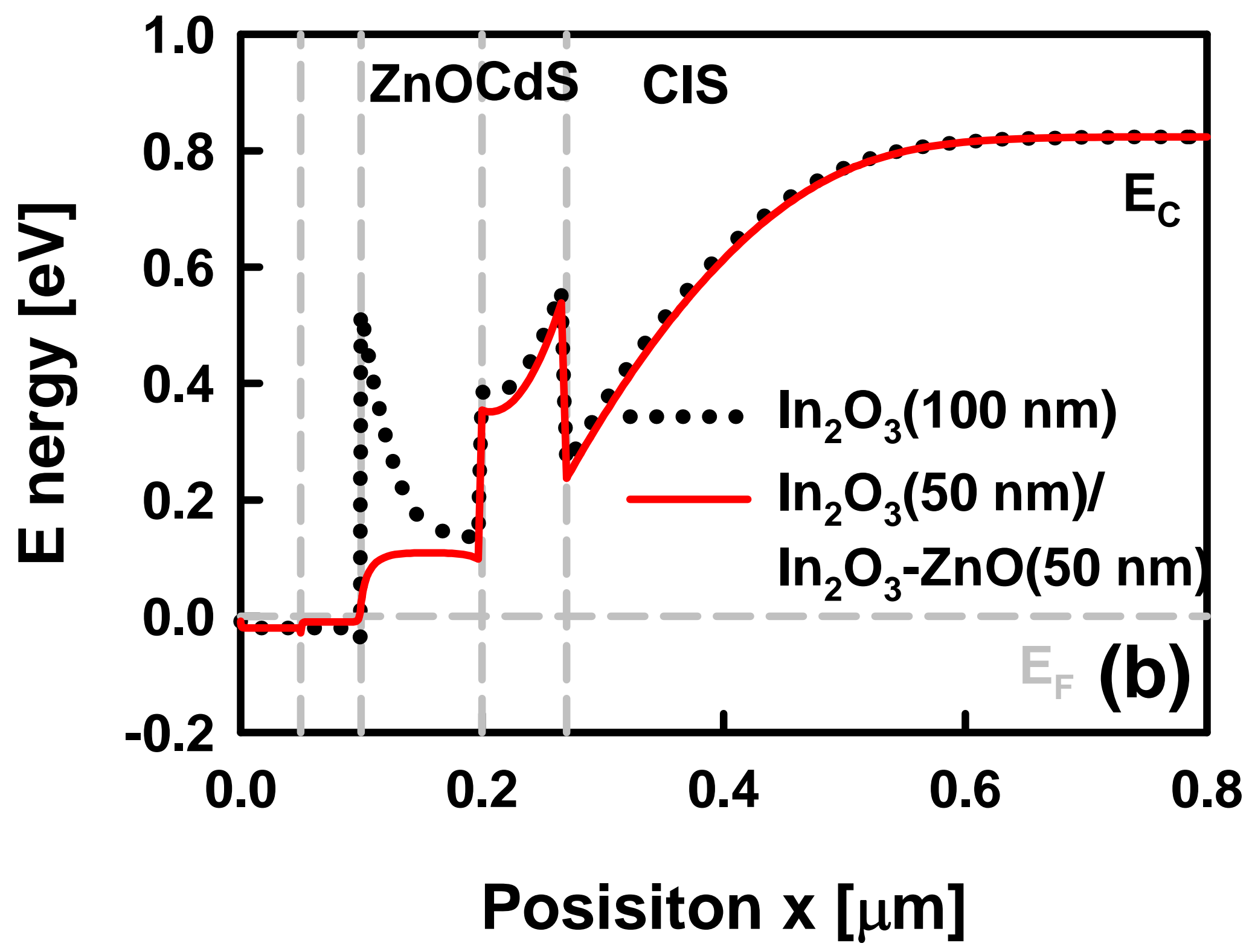




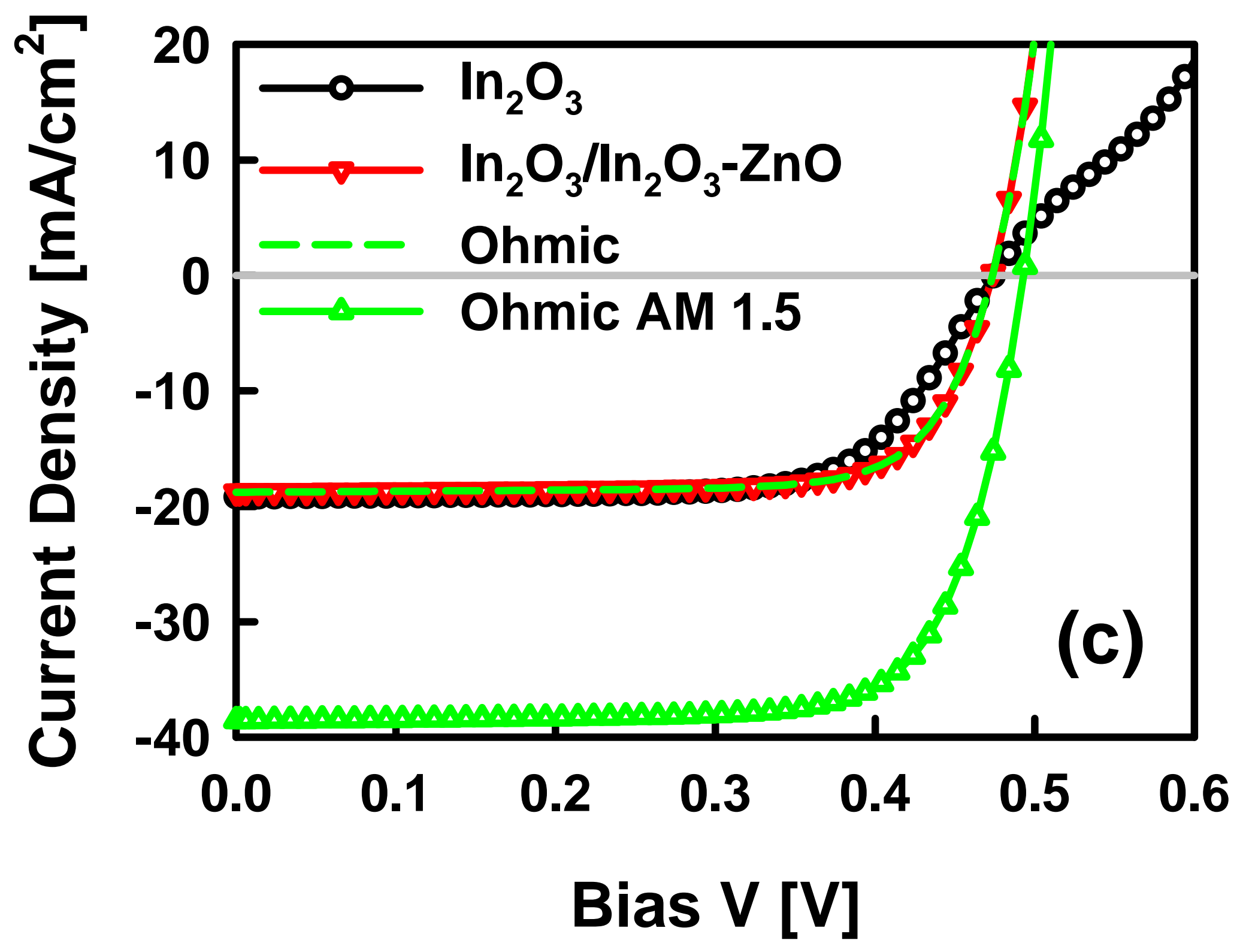




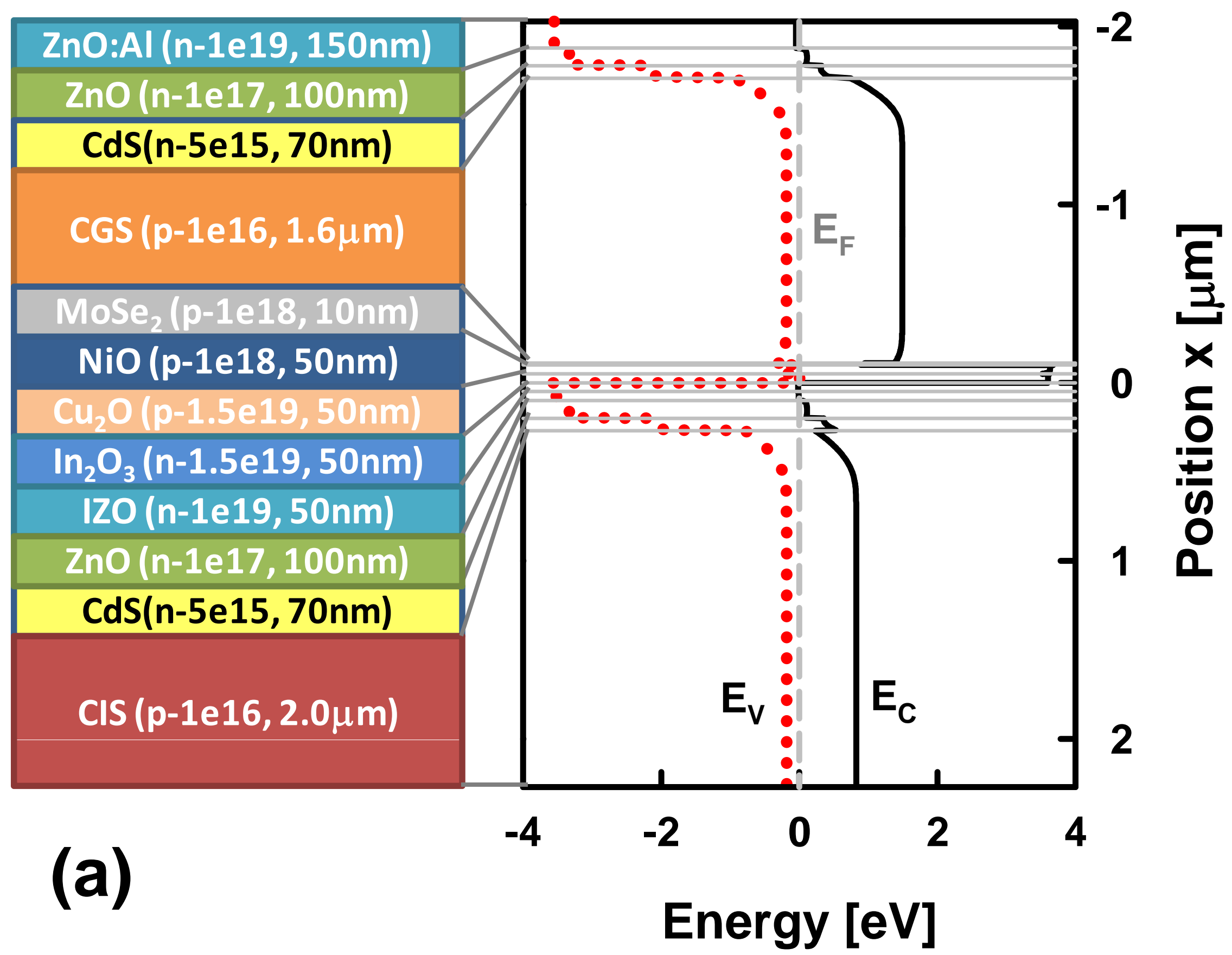




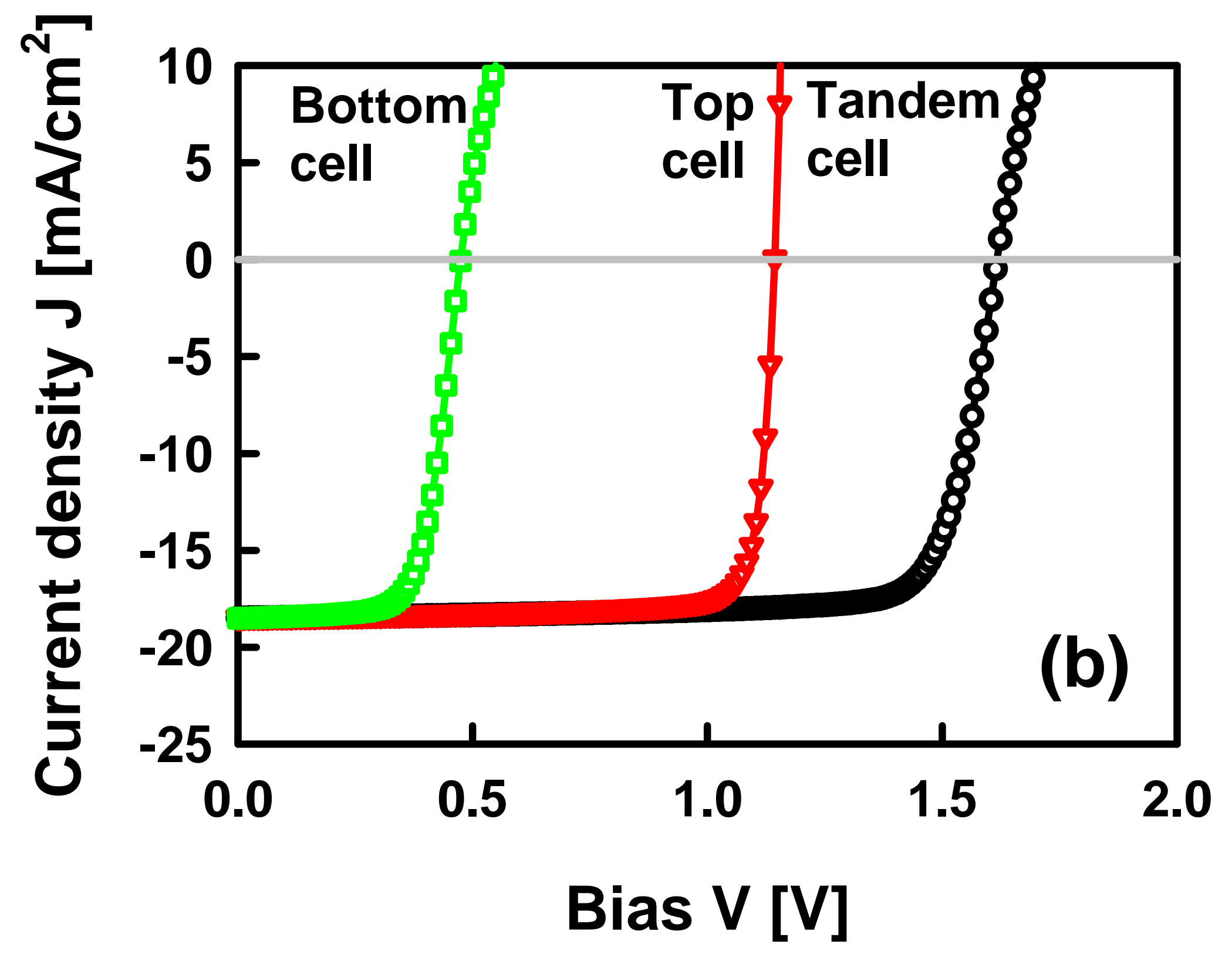

